\title{
COMMENTS
}

\section{EXCULPATORY CLAUSES \\ THE HISTORICAL IMPACT OF COMMON-CARRIER LAW AND THE MODERN RELEVANCE OF INSURANCE}

Recently the Supreme Court held that it was against public policy for a tug boat to exculpate itself by contract from negligence liability to an unmanned tow, announcing as the principal rationalizations for the holding that it would "(1) ... discourage negligence by making wrongdoers pay damages, and (2) ... protect those in need of goods or services from being overreached by others who have power to drive hard bargains." The Court, quite correctly, claimed no originality in these reasons; they may fairly be said to represent the best modern thought on the rationale of public policy in the law of exculpation. ${ }^{2}$

Neither reason, however, is entirely satisfactory. Mr. Justice Frankfurter, in dissent, pointed out the main difficulty ${ }^{3}$ with the first reason:

1 Bisso v. Inland Waterways Corp., 349 U.S. 85, 91 (1955). Justice Black delivered the opinion of the Court, Justice Douglas concurred in a separate opinion, and Justices Frankfurter, Reed and Burton dissented. See also the companion cases, Boston Metals Co. v. The Winding Gulf, 349 U.S. 122 (1955), and United States v. Nielson, 349 U.S. 129 (1955).

2 "There are three bases for deciding that a bargain, otherwise valid, which exempts one from future liability to another that would arise except for the bargain is invalid because the parties are in a certain relationship to each other. First, some relationships are such that once entered upon they involve a status requiring of one party greater responsibility than that required of the ordinary person, and, therefore, a provision avoiding liability is peculiarly obnoxious. Second, in many relationships there is a situation where one person is dealing contemporaneously with several others, so that a bargain limiting his liability to one of them is considered to have a tendency to lead to conduct injurious to others. Third, a relation often represents a situation in which the parties have not equal bargaining power, and one of them must either accept what is offered or be deprived of the advantages of the relation. These reasons are not necessarily exclusive of one another." 6 Williston, Contracts $\$ 1751 \mathrm{c}$ (1938). Consult also Rest. Contracts $\$ \$ 574,575$ (1932). The leading article on the subject generally is, The Significance of Comparative Bargaining Power in the Law of Exculpation, $37 \mathrm{Col}$. L. Rev. 248 (1937). Consult also Validity of Contractual Provision by One other than Carrier or Employer for Exemption from Liability, or Indemnification, for Consequences of own Negligence, 175 A.L.R. 8 (1948).

${ }^{3}$ A related objection is that there is no very precise evidence indicating that tort liability is generally a deterrent to negligent conduct. Professor James has suggested that there are other factors of at least equal force which tend to make people careful, such as danger to the negligent party, disruption of normal business routine destruction of the negligent person's property, and bad public and labor relations. James, Accident Liability Reconsidered: The Impact of Liability Insurance, 57 Yale L.J. 549 (1948). Professor James was primarily concerned with personal injury liability rather than the damage to property typically associated with exculpatory clauses, but the same reasons would appear to apply to both situations. Consult, also, authorities cited in Prosser, Torts 344 n. 61 (2d ed., 1951). 
The argument is made that permitting the parties to grant immunity to the tug will stimulate irresponsibility, or, at least, that it is necessary to force the tug to bear losses resulting from its negligence in order to provide an incentive to reasonable care. In the commercial setting of the towage industry this argument has little force, unless we are prepared also to forbid the tug to insure against such losses or liabilities. If not, then the question ultimately is whether public policy requires that the tug, rather than the tow, shall bear the cost of insurance. ${ }^{4}$

Analytically, the second reason also presents problems. It is difficult to see how inequality of bargaining power alone can justify voiding an exculpatory clause. ${ }^{5}$ Inequality of bargaining power will, if sufficiently aggravated, justify a court in examining the terms of a contract to determine their reasonableness in light of the factual background of the contract ${ }^{6}$ and to void those clauses which offend the court's sense of fairness. ${ }^{7}$ The cases upholding exculpatory clauses indicate

${ }^{4}$ Bisso v. Inland Waterways Corp., 349 U.S. 85, 118-19 (1955).

${ }^{5}$ Perhaps it should be pointed out that an exculpatory clause will always appear in a contract which has some other object as its main purpose. Usually the clause appears in a situation where some interest in property is given by one party to the other, e.g., bailment contracts, trust instruments, or, with the exculpation usually going the other way, leases. Occasionally exculpatory clauses appear when control over the person of one party is temporarily given to the other, e.g., employment contracts, carriage of passengers. Difficult to classify in this manner are exculpatory clauses in connection with telegraph messages.

There is a clear distinction between an exculpatory clause and an indemnity contract. In the latter the risk of injury to third persons (or to the indemnitee) is shifted to the indemnitor. With an exculpatory clause, the person who would have to carry the risk of his own negligence attempts to shift it onto the person who would be injured by his negligence. Though the factual distinction is simple, it is more difficult to see why different rules should be applied. As one court asked, "Neither law nor public policy prevents the ordinary contractor from buying from a third party indemnity from the pecuniary result of his own negligence. This is legitimate as insurance. How does the same process, with identical result, become illicit simply because they are those of the original and basic contract rather than a collateral one for conventional insurance?" Northern Pac. Ry. Co. v. Thornton Bros. Co., 206 Minn. 193, 197, 288 N.W. 226, 228 (1939).

${ }^{6}$ In exculpatory litigation the general rule is that litigants are to be considered as members of a class rather than as individuals. Consult Validity of Contractual Provision ... for Exemption from ... Consequences of Own Negligence, 175 A.L.R. 8, 16-17 (1948). In most of the cases where there has been an effort to exculpate from liability for negligence there is a well-defined legal relationship created by the main purpose of the contract. The importance of the relationship in determining the validity of an exculpatory clause is illustrated by the accepted doctrine in the parking lot cases. If the customer parks his own car and takes the keys with him, the proprietor of the lot has merely granted a license to the customer and consequently is not liable if the car is lost through negligence. On the other hand, if an attendant parks the car and keeps the keys, the proprietor is a bailee for hire and liable for any loss. Authorities cited note 171 infra. No one has ever suggested that running a parking lot on the license basis is contrary to public policy, but the efforts of proprietors of parking lots run on the bailee basis to avoid negligence liability by contract have run into considerable judicial hostility.

7 The circumstances under which a court should feel free to rewrite a contract are beyond the scope of this note. The relevance of inequality of bargaining power is based on the theory that the rules of contract law assume equality of bargaining power, and when that assumption is invalid those rules ought not to be mechanically applied. Consult Wright, Opposition of the Law to Business Usages, 26 Col. L. Rev. 917 (1926). It should be noted that the concept of inequality of bargaining power in this context is extremely loose and ill-defined. 
that contracting out of negligence liability is not per se unfair or unreasonable. ${ }^{8}$ Therefore it would seem that something more than a finding of inequality of bargaining power is necessary to justify a court in striking down an exculpatory clause.

This most recent decision of the Court on the subject is merely one of many modern cases voiding exculpatory efforts on the same general grounds and subject to the same logical difficulties. The mere repetition of implausible rationale suggests that the origins of the difficulty are historical rather than analytical, and it is believed that much of the modern confusion can be traced to the somewhat older confusion surrounding the rule that a common carrier cannot by contract avoid liability for negligence. This comment will summarize the origins of this common-carrier doctrine to show how the confusion there is reflected in some of the many modern relationships where there is a developed law of exculpation. ${ }^{9}$ Finally some tentative conclusions will suggest how the law might better approach contractual efforts to avoid negligence liability.

\section{I}

To understand why a common carrier ${ }^{10}$ cannot contract out of negligence liability it is necessary first to understand the rationale of the rule which makes a carrier liable as an "insurer."

In the earliest English law no clear distinction was made between the concepts of ownership and possession of chattels; as a corollary of this it was essential in an action to recover possession that the plaintiff show that he was in possession at the time the chattel was wrongfully taken.$^{12}$ From this it followed that only the bailee had possessory remedies against third persons and that the bailor was limited to an action against the bailee. ${ }^{13}$ Holmes argued that from

${ }^{8}$ Consult authorities cited note 142 infra.

$\checkmark$ Areas not discussed in this note are: common carriers by sea, telegraph and telephone, trusts, stop-payment orders, employment contracts and common carriers of passengers. The reasons for exclusion are, aside from limitations of space, either that the cases show no appreciable influence from the carrier doctrines or that the law has now become largely academic through statute. Although the law of carriers by sea has a common early development with the land-carrier cases, its development since that time has been largely independent.

${ }^{10} \mathrm{It}$ should be noted that throughout this comment, unless it is stated to the contrary, "common carrier" means common carrier of freight by land and not common carrier of passengers or of freight by sea.

11 The phrase is not strictly accurate in that a carrier is not liable for acts of God or the public enemy.

12 Holmes, The Common Law 167 (1881); 3 Holdsworth, History of English Law 337 (3d ed., 1923); Fletcher, Carrier's Liability 2-4 (1932).

${ }^{13}$ Holmes, op. cit. supra note 12, at 167; 3 Holdsworth, op. cit. supra note 12, at 337-38; 2 Pollock and Maitland, History of English Law 170 (2d ed., 1899). Compare Bordwell, Property in Chattels, 29 Harv. L. Rev. 501, 505 et seq. (1916), who believed that the bailor was given remedies a century before 1483 , the date that Holdsworth gives as approximately the time when the bailor could sue third parties who interfered with the bailee's possession. Consult Paton, Bailment in the Common Law 55 et seq. (1952), and Fletcher, op. cit. supra note 12, at 9. 
this the rule evolved that the bailee was liable to the bailor for loss of the goods regardless of fault in the bailee. ${ }^{14}$ This rule making the bailee absolutely liable for loss of the goods lasted long after the bailor gained actions against the wrongdoer in possession, ${ }^{15}$ and eventually the rule became, by Holmes' view inverted: the bailee could sue the wrongdoer because he was liable over to the bailor for the loss. ${ }^{16}$

It is clear that after the bailor was given possessory remedies against third parties, the absolute liability of bailees lost any rational justification which it may have had. One of the forces undercutting this extraordinary liability was its limitation in the bailment contract; perhaps an example of the movement from status to contract. In Southcote's Case ${ }^{17}$ (1601) Lord Coke in addition to reaffirming the absolute liability of a bailee, ${ }^{18}$ warned his readers that:

[1] $t$ is good policy for him who takes any goods to keep, to take them in a special manner, scil. to keep them as he keeps his own goods, or to keep them the best he can at the peril of the party; or if they happen to be stolen or purloined, that he shall not answer for them. ...19

This is no authority that a carrier could necessarily stipulate out of his extraordinary liability, ${ }^{20}$ as it appears to apply only to bailees who "take goods to

${ }^{14}$ Holmes, op. cit. supra note 12, at 167; 3 Holdsworth, op. cit. supra note 12, at 337-39. Compare Beale, The Carrier's Liability: Its History, 11 Harv. L. Rev. 158 (1897), and Paton, op, cit. supra note 13, at 66 et seq. The objection to the Holmes theory is mainly that what evidence is available of the law between Glanville (circa 1187), and Southcote's Case, 4 Co. Rep. 83b., 76 Eng. Rep. 1061 (K.B., 1601), indicates that the liability of bailees was not continuously absolute.

It is important to note that the absolute liability was only for loss, not damage. The absolute liability was on a writ of detinue, and a return of the article by the bailee, even if damaged, was a defense to that action. The remedy for damage was trespass on the case which required a showing of negligence (misfeasance) or, where the damage was due to failure to act (nonfeasance), both that failure and a special undertaking. The latter would be implied if the defendant were employed in a "common" or quasi-public employment. Fletcher, op. cit. supra note 12, at 104-5. On the common employment consult note 28 infra.

${ }^{15}$ Authorities cited note 13 supra. If not continuous, the rule was certainly revived by Southcote's Case, 4 Co. Rep. 83b., 76 Eng. Rep. 1061 (K.B., 1601).

${ }^{16}$ Holmes, op. cit. supra note 12, at 167. Compare 3 Holdsworth, op. cit. supra note 13 , at 342-43. Pollock and Maitland were skeptical as to the neatness of this argument: "Perhaps we come nearest to historical truth if we say that between the two old rules there was no logical priority. The bailee had the action because he was liable and was liable because he had the action." 2 Pollock and Maitland, op. cit. supra note 13, at 171-72.

174 Co. Rep. 83b., 76 Eng. Rep. 1061 (K.B., 1601).

${ }^{18}$ Presumably because the bailee had the remedy (though by this time the bailor also did): "If traitors break into a prison it shall not discharge the Gaoler: otherwise of the King's enemies; for in the one case he may have his remedy and recompense, and in the other not." 4 Co. Rep. 83b., 84a., 76 Eng. Rep. 1061, 1063 (K.B., 1601). The exception of Jiability for loss due to the King's enemies was probably intended to extend to bailees generally, and the same would be true of the rationale. Consult Fletcher, op. cit. supra note 12, at 32-33.

${ }^{19}$ Southcote's Case, 4 Co. Rep. 83b., 84a., 76 Eng. Rep. 1061, 1063 (K.B., 1601).

${ }^{20}$ Fletcher, op. cit. supra note 12, at 180. Holt, dissenting in Lane v. Cotton said, "He has a reward, which is the reason in the case of innkeepers, hoymen, etc. who are bound to keep safely, and answer all neglects of those that act under them, and so they would be, though 
keep."21 It certainly does not warrant the interpretation that a carrier could contract out of liability for negligence.

The famous case of Coggs $v$. Bernard ${ }^{22}$ is significant for these purposes in two respects: (1) The field of persons liable for loss without fault was restricted to those bailees exercising a public employment, e.g., common carriers, and (2) Lord Holt announced a new justification for the carrier's extraordinary liability.

The law charges this person thus intrusted to carry goods, against all events but acts of God, and of the enemies of the King. . . . And this is a politick establishment, contrived by the policy of the law, for the safety of all persons, the necessity of whose affairs oblige them to trust these sorts of persons, that they may be safe in their ways of dealing; for else these carriers might have an opportunity of undoing all persons that had any dealings with them, by combining with thieves, etc. and yet doing it in such a clandestine manner, as would not be possible to be discovered. And this is the reason the law is founded upon in that point. ${ }^{23}$

Collusion with thieves and difficulty of proof ${ }^{24}$ are thus the reasons for continuing the absolute liability of carriers. It has been suggested that "act of God" was meant by Holt to be liberally construed as meaning "inevitable accident," and that even this liability was to be limited to loss of the goods-a claim for damage would require a showing of negligence..$^{26}$ If so, it was Lord Mansfield in Forward v. Pittard, ${ }^{27}$ eighty years later, who established the doctrine that a common carrier was liable as an "insurer." He said:

But there is a further degree of responsibility by the custom of the realm, that is, by the common law; a carrier is in the nature of an insurer. It is laid down he is liable for

they should expressly caution against it." 1 Salk. 17, 18, 12 Mod. 472 (K.B., 1701). The earliest reference to a carrier's power to limit his liability by contract is in Kenrig v. Eggleston, Aleyn 93 (1648). In Mors v. Slew, Hale is reported to have said, "[The master of a ship] might have made a caution for himself, which he omitting and taking in the goods generally, he shall answer for what happens." 1 Vent. 238, 3 Keb. 135 (K.B., 1671). Consult also 7 Holdsworth, op. cit. supra note 12 at $452-53$.

${ }^{21}$ But note the sense of the word "keep" in the quote in note 20 supra.

22 Ld. Raym. 909, 92 Eng. Rep. 107 (K.B., 1703).

${ }^{23}$ Tbid., at $918,112$.

24 In Lane v. Cotton, 1 Salk. 17, 12 Mod. 472 (K.B., 1701), Lord Holt expanded the reasoning and made somewhat more distinct the difficulty-of-proof point: "[F]or if they were not chargeable for loss of goods, without assigning any particular default in them, they having such opportunity as they have by the trust reposed in them to cheat all people, they would be so apt to play the rogue and cheat people, without almost a possibility of redress, by reason of the difficulty of proving a default particularly in them, that the inconveniency would be very great." Thid., at 481-82, 18.

${ }^{25}$ Beale, op. cit. supra note 14, at 167; Fletcher, op. cit. supra note 12, at 147-51, 156-61; Holmes, op. cit. supra note 12, at 195-205. It is said that this interpretation conforms to the reason for the rule, and this would certainly be true if the reason were limited to collusion with thieves. One may, however, have reservations where emphasis is put on the difficulty of proof.

26 Fletcher, op. cit. supra note 12, at 150; Holmes, op. cit. supra note 12, at 199-200.

${ }^{27} 1$ Dun. \& East T.R. 27 (K.B., 1785). 
every accident, except by the act of God, or the King's enemies . . . or by such act that could not happen by the intervention of man. . . .

If an armed force come to rob the carrier of the goods, he is liable: and a reason is given in the books, which is a bad one, viz. that he ought to have a sufficient force to repel it: but that would be impossible in some cases, as for instance in the riots in the year 1780. The true reason is ... for fear it may give room for collusion, that the master may contrive to be robbed on purpose, and share the spoil. ${ }^{28}$

Considering the reasons given for the establishment of insurer liability for carriers, one would not expect the English courts to allow that liability to be minimized by contract. ${ }^{29}$ If the carrier could stipulate to be free of liability for robbery, the dangers of collusion would tempt him to do the very things which the policy of the law sought to avoid. Nor would it be expected that the carrier could be allowed to shift the burden of proof by contract so that the shipper would have to show some sort of default in order to recover. The English courts, however, did not turn to the rationale of the insurer liability of carriers, but rather to the developing notions of freedom of contract, eventually arriving at the position that a common carrier could stipulate out of all non-wilful liability including that for negligence.

The first significant case involving a limitation of liability by a carrier was Gibbon v. Paynton ${ }^{30}$ (1769). The proprietor of a stage coach had posted a notice that he would not be liable for goods of high value unless their value was declared and a premium paid. ${ }^{31}$ The plaintiff had concealed money in an old nail bag and sent it to London buried in a load of hay. "The bag and the hay arrived safe; but the money was gone." ${ }^{32}$ By holding that the plaintiff could not recover, the court indirectly gave effect to the notice. The holding was apparently based on estoppel: $:^{33}$ in the presence of such a notice a shipper who assigns goods a low

${ }^{28}$ Ibid., at 33-34. The actual decision in the case reduced the act-of-God exception to its literal meaning. The defendant was held liable for the loss of a load of hops caused by a fire in a building 100 feet away which raged with "inextinguishable violence" though it was admitted that there was no negligence on his part in placing the load there, and it was implied that if the fire had been caused by lightning the plaintiff would not have recovered.

The bad reason "given in the books" was probably the "custom of the realm," that is, the extraordinary position of those engaged in a common or quasi-public employment. Beale lists them as including, "innkeepers, victuallers, taverners, smiths, farriers, tailors, carriers, ferrymen, sheriffs, and gaolers. Each of these persons, having undertaken the common employment, was not only at the service of the public, but was bound so to carry on his employment as to avoid losses by unskilfulness or improper preparation for the business." Beale, op. cit. supra note 14, at 163 .

${ }^{29}$ At least one English judge believed this, Lord Holt dissenting in Lane v. Cotton, 1 Salk. 17, 12 Mod. 472 (K.B., 1701), and one American, Cowen in Cole v. Goodwin, 19 Wend. (N.Y.) 251 (1838).

${ }^{30} 4$ Burr. 2299 (K.B., 1769).

${ }^{31}$ The notice did not include any statement about the paying of a premium, but the court inferred it from general usage.

32 Gibbon v. Paynton, 4 Burr. 2299 (K.B., 1769).

${ }^{33}$ The court spoke in terms of "fraud" and "concealment" but it seems clear that estoppel would be the modern phraseology. Note also that Yates, J., while agreeing on the "fraud" point also said, "[T] hat a carrier miay make a special acceptance; and that this was a special acceptance." Ibid., at 2302. 
value for freight charge will not be heard to give them a high value if they are lost. Technically, these notices ${ }^{34}$ were not contracts; the willingness of the courts to honor this method of limiting liability without insisting, as they later did, that the shipper have actual knowledge of the terms of the notice, ${ }^{35}$ indicates at least an atmosphere of hostility toward the rationale of the "insurer" doctrine.

It is difficult to make any further generalizations about the notice law because the holdings were never very precise as to what was within and what was without the protection of the notice. ${ }^{36}$ In the early cases there is at least an indication that the notice was effective against all losses ${ }^{37}$ except those resulting from wilful misfeasance or what would now probably be called wilful default..8 Later there is talk of the notice not protecting a carrier from liability for gross negligence, ${ }^{39}$ and still later it becomes clear that gross negligence is being given to the jury on instructions that make it industinguishable from "ordinary" negligence. ${ }^{40}$ Never, however, is any doubt expressed as to the validity of a "special" contract which clearly put all risks of negligence on the shipper. ${ }^{41}$

It is evident from the many statements of the judges that they were bothered by the notice doctrine, both because they felt that the notices were not "special" contracts, ${ }^{42}$ and also because they knew that it was inconsistent with the

${ }^{34}$ The notices in this period were all in this form, but with the addition of a clause specifically demanding a premium. Only two exceptions are known, in Maving v. Todd, 1 Stark. 72 (Nisi Prius, 1815) (the notice stipulated that the carrier would not be liable for fire) and Leeson v. Holt, 1 Stark. 186 (Nisi Prius, 1816) (in effect, all risks on the shipper).

${ }^{35}$ Consult Fletcher, op. cit. supra note 12.

${ }^{36}$ The confusion was very accurately summarized by Baron Parke in Wyld v. Pickford, 8 M. \& W. 442 (Ex., 1841).

${ }^{37}$ Nicholson v. Willan, 5 East 507 (K.B., 1804); Harris v. Packwood, 3 Taunt. 264 (C.P., 1810). See also Graham, B., in Bodenham v. Bennett, 4 Price 31 (Ex., 1817). A good indication of the trend of the law during this period can be had by comparing Nicholson $v$. Willan, supra, with Sleat v. Fagg, 5 B. \& Ald. 342 (K.B., 1822). 1812).

${ }^{38}$ Ellis v. Turner, 8 Dun. \& East T.R. 531 (K.B., 1800); Beck v. Evans, 16 East 244 (K.B.,

${ }^{39}$ Bodenham v. Bennett, 4 Price 31 (Ex., 1817); Smith v. Horne, 8 Taunt. 144 (C.P., 1818); Birkett v. Willan, 2 B. \& Ald. 356 (K.B., 1819) (failure to give gross negligence instruction required new trial); Batson v. Donovan, 4 B. \& Ald. 21 (K.B., 1820) (Best, J.); Duff v. Budd, 3 Brod. \& B. 177 (C.P., 1822) (finding of gross negligence made question of whether plaintiff had actual knowledge of notice unnecessary); and Brooke v. Pickwick, 4 Bing. 218 (C.P., 1827) (same).

${ }^{40}$ In Batson v. Donovan, Best, J. in dissent, defined gross negligence as "[S]omething much short of ... [conduct highly blameable] will be sufficient to make a carrier responsible. He and his servants must take all the care that is necessary for the preservation of the property committed to his charge. They must take the same care of it that a prudent man would take of his own property." 4 B. \& Ald. 21, 30 (K.B., 1820). This was evidently the definition of gross negligence which Dallas, C. J., gave to the jury in Duff v. Budd, 3 Brod. \& B. 177, 182-83 (C.P., 1822). See also Wyld v. Pickford, 8 M. \& W. 442 (Ex., 1841); and Hinton v. Dibbin, 2 Q.B. 646, 661 (1842).

41 This is still the English position, Ludditt v. Ginger Coote Airways, Ltd., 177 L.T.R. 223 (Privy Coun., 1947); see also Adler v. Dickson, 2 Ll. L.L. Rep. 267 (C.A., 1954).

42 Though the distinction between a "special" contract and the notice is unimportant for the purpose of determining a carrier's power to contract out of the liability imposed by law, 
doctrine of carriers' insurer liability. ${ }^{43}$ Though there were some judges who wanted to interpret the notices as exculpating the carrier only from extraordinary, and not from negligence liability, ${ }^{44}$ this was never explicitly done ${ }^{45}$ Nor was any explanation ever offered for the rule that a notice was good against simple negligence but not against gross. ${ }^{46}$ The greatest inconsistency with the "insurer" doctrine, however, was the fact that the notice shifted the burden of proof; in order to hold the carrier liable it was necessary for the shipper to prove some sort of negligence. ${ }^{47}$

In 1830 Parliament passed the first Carrier's Act ${ }^{48}$ under which the courts removed the degrees-of-negligence difficulty. As construed, this statute allowed a carrier to limit his liability by notice provided that the shipper had actual knowledge of its terms. ${ }^{49}$ There was nothing in the statute which either prohibited or authorized contracting out of negligence liability, ${ }^{50}$ but the courts used it as an explanation for their final holding that a carrier could exculpate himself from negligence liability, gross or otherwise. ${ }^{51}$ The act of 1830 was illtimed; it corresponded with the emergence of the railroad as a principal means of transport, and with the railroad the carrier became a far less sympathetic

it was a very important distinction at the time and was picked up in this country. Consult, e.g., Hollister v. Nowlen, 19 Wend. (N.Y.) 234 (1838); Cole v. Goodwin, 19 Wend. (N.Y.) 251 (1838); and Gould v. Hill, 2 Hill (N.Y.) 623 (1842).

${ }^{43}$ Lord Mansfield in Nicholson v. Willan, 5 East 507 (K.B., 1804); Sir James Mansfield, C.J., in Harris v. Packwood, 3 Taunt. 264 (C.P., 1810); Burrough, J., in Smith v. Horne, 8 Taunt. 144 (C.P., 1818); Best, C.J., in Brooke v. Pickwick, 4 Bing. 218 (C.P., 1827). Note also this interesting statement of Lord Mansfield: "At first the rule [of insurer's liability] appears to be hard, but it is settled on principles of policy, and, when once established, every man contracts with reference to it, and there is no hardship at all." Barclay v. CuCulla y Gana, 3 Doug. 389, 390-91 (K.B., 1784) (admiralty).

${ }^{44}$ Lawrence, J., in Harris v. Packwood, 3 Taunt. 264 (C.P., 1810) (before he admitted his error); Wood, B., in Bodenham v. Bennett, 4 Price 31 (Ex., 1817); and Best, J., in Batson v. Donovan, 4 B. \& Ald. 21, 31 (K.B., 1820) (dissenting).

- ${ }^{45}$ The courts did come to that result by their definition of gross negligence. Consult note 40 supra.

${ }^{46}$ This problem is discussed further at 339-41 infra.

47 Wyld v. Pickford, 8 M. \& W. 442 (Ex., 1841). Note also Best, C.J., in Riley v. Horne, 5 Bing. 217, 220 (K.B., 1828), discussing the importance of the proof point.

$4811 \mathrm{Geo}$. IV and 1 Will. IV, c. 68 (1830).

${ }^{49}$ Hinton v. Dibbin, 2 Q.B. 646 (1842).

${ }^{50}$ The relevant sections were $\S I V$, "[N]o public Notice or Declaration . . . shall be deemed or construed to limit or in anywise affect the Liability at Common Law of any . . . common Carrier . . . but that all . . . common Carriers ... shall ... be liable, as at Common Law ... any public Notice or Declaration by them made and given contrary thereto, or in anywise limiting such Liability, notwithstanding." And \& VI, "Provided ... That nothing in this Act contained shall extend or be construed to annul or in anywise affect any special Contract between such ... common Carrier, and any other Parties, for the Conveyance of Goods and Merchandizes." 11 Geo. IV and 1 Will. IV, c. 68 (1830).

${ }^{51}$ Carr v. Lancashire \& Yorkshire Ry. Co., 7 Ex. 707 (1852). See also Hinton v. Dibbin, 2 Q.B. 646 (1842), overruling Owen v. Burnett, 2 Cr. \& M. 353, 4 Tyrwh. 133 (Ex., 1834). 
character. In time Parliament passed the Railway and Canal Traffic Act of $1854^{52}$ which, as construed, restrained the power of carriers to limit their liability by contract to those terms which a court should think "just and reasonable."53

The notion that there ought to be some consistency between the reason for the carrier's liability as an insurer and his power to contract out of that liability, though neglected by the English courts, was taken up by some of the American courts when the problem was first presented on this side of the Atlantic. In the first case, in 1838, the New York court came to the conclusion that a carrier could in no fashion limit his liability by contract-or in other words that the English notice cases were wrong. ${ }^{54}$ Justice Cowen delivered an exceedingly erudite opinion reviewing the English cases at length. ${ }^{55} \mathrm{He}$ could find no significant improvement in morals in New York over England. ${ }^{56}$ Because there was a danger of collusion with thieves, the law imposed a higher standard of liability on common carriers, and that very reason prevented, to his mind, any power in the carrier to limit that responsibility by notice or contract. Thus he concluded that:

[The carrier] shall not be allowed in any form to higgle with his customer and extort one exception and another, not even by express promise or special acceptance any more than by notice. He shall not be privileged to make himself a common carrier for his own benefit, and a mandatory, or less, to his employer. He is a public servant with certain duties defined by law; and he is bound to perform those duties. ${ }^{57}$

Most American courts, however, followed the English cases in allowing the carrier to avoid liability by notice or contract for loss or damage not due to the negligence of the carrier; $;^{58}$ a few early cases even allowed a carrier to contract out of negligence liability. ${ }^{59}$ But the definitive American answer to this problem of the carrier's power to contract out of negligence liability was delivered by the Supreme Court in Railroad Co. v. Lockwood. ${ }^{60}$

The Lockwood case, which came before the Court in 1873, held that a common s2 17 \& 18 Vict., c. 31 (1854).

${ }^{53}$ Peek v. North Staffordshire Ry. Co., 10 H.L. Cas. 473 (1863).

"Cole v. Goodwin, 19 Wend. (N.Y.) 251 (1838). The first carrier case which at all involved the power to contract out of liability was a companion case to the above, but it turned on the issue of whether the notice had to be brought home to the shipper. Hollister v. Nowlen, 19 Wend. (N.Y.) 234 (1838).

so Others have praised Justice Cowen. Consult Llewellyn, On Warranty of Quality, and Society, 36 Col. L. Rev. 699, 741 (1936).

BB "Nor was this said of a barbarous people or a barbarous age; but in the reign of Queen Anne, of morals, arts and arms, an age distinguished as the Augustan Era of England.... It would be arrogant in any nation to claim a state of morals superior to those of England and especially to Scotland, where the same rigor prevails; still more arrogant, not to say profane, to claim a national perfectability so high as to rise above temptation." Cole v. Goodwin, 19 Wend. (N.Y.) 251, 272 (1838).

${ }^{57}$ Ibid., at 281. The "express promise" was dicta but it was made a holding in Gould v. Hill, 2 Hill (N.Y.) 623 (1842). See also Fish v. Chapman \& Ross, 2 Kelly (Ga.) 349 (1847).

s8 1 Hutchinson, Carriers $\$ 401$ (3d ed., 1906).

59 Thid., at $\$ \$ 450-51$.

${ }^{60} 17$ Wall. (U.S.) 357 (1873). 
carrier could stipulate only for "just and reasonable" exemptions from his insurer's liability, and that a stipulation against negligence liability was not reasonable. Justice Bradley devoted most of his opinion to finding that the shipper and carrier were not on equal bargaining terms, ${ }^{61}$ and concluded finally that because of this fact contracts of common carriers would always be subject to close scrutiny by the Court. At one point he observed that it was "just and reasonable" for carriers to stipulate that they would,

[N]ot be responsible for losses happening by sheer accident, or dangers of navigation that no human skill or vigilance could guard against ... [because] [t]he improved state of society and the better administration of the laws, had diminished the opportunities of collusion and bad faith on the part of the carrier, and rendered less imperative the application of the iron rule, that he must be responsible at all events. ${ }^{62}$

In saying this Justice Bradley put himself in a very difficult position. The clear implication is a rejection of the accepted rationalization for the extraordinary liability of carriers-common carriers could, therefore, contract out of the extraordinary aspects of their liability. ${ }^{63}$ Why the carrier under these circumstances was, underneath it all, liable as an insurer, Bradley did not explain. ${ }^{64}$ Compared with Cowen's problem which was only to put insurer liability and the power to contract out of that liability together, Bradley set for himself the problem of showing why a carrier could contract out of his extraordinary liability but not out of his ordinary negligence liability. Basically, the problem was what was special about carriers that distinguished them from other bailees for hire who could at that time contract out of negligence liability. ${ }^{65}$ To this point Bradley said:

In regulating the public establishment of common carriers, the great object of the law was to secure the utmost care and diligence in the performance of their important duties. ... Hence the common-law rule which charged the common carrier as an insurer. Why charge him as such? Plainly for the purpose of raising the most stringent motive for the exercise of carefulness and fidelity in his trust.... It is obvious, therefore, that if a carrier stipulate not to be bound to the exercise of care and diligence, but to be at liberty to indulge in the contrary, he seeks to put off the essential duties of his employment. And to assert that he may do so seems almost a contradiction in terms. ${ }^{66}$

${ }^{61}$ So, of course, did Justice Cowen: "The traveler and bailor is under a sort of moral duress, a necessity of employing the common carrier under those legal arrangements which allow any number of persons to assume that character, and thus discourage and supersede the provision for other modes of conveyance." Cole v. Goodwin, 19 Wend. (N.Y.) 251, 281 (1838).

62 Railroad Co. v. Lockwood, 17 Wall. (U.S.) 357, 380-81 (1873).

${ }^{63}$ The Court was pretty well bound on this question by its earlier decisions in New Jersey Steam Navigation Co. v. The Merchants' Bank, 6 How. (U.S.) 343 (1848), and York Co. v. Central R.R., 3 Wall. (U.S.) 107 (1865).

64 Compare Justice Blatchford in Hart v. Pennsylvania R.R. Co., 112 U.S. 331 (1884), where he observed that a carrier was liable for the full loss "if he does not make a special acceptance. This is reasonable, because he can always guard himself by a special acceptance. . . ." Ibid., at 340 . See also note 43 supra.

65 Story, Bailments $\$ \$ 31-32$ (9th ed., Schouler, 1878).

${ }^{68}$ Railroad Co. v. Lockwood, 17 Wall. (U.S.) 357, 377-78 (1873). 
As a statement of the rationale distinguishing carriers from other bailees, this leaves much to be desired. Of course the basic premise as to the rationale of insurer liability was historically wrong; ${ }^{67}$ but worse than that, after saying earlier that changed conditions had made obsolete the accepted rationale for the insurer doctrine, Bradley used the same obsolete doctrine of insurer liability as the basis for the distinction between ordinary bailees' and common carriers' power to contract out of negligence liability. His extensive discussion of inequality of bargaining power contributes nothing to the rationale of the distinction. ${ }^{68}$

In short, the carrier cases are not very helpful in the search for the factors in a contractual relationship that prevent contracting out of negligence liability ${ }^{69}$ About all that can be learned is that for reasons unknown carriers cannot so transfer the risk of their negligence. But so stated the rule is misleading if not wrong. Another common-law doctrine was developed which permitted a shipper and carrier to agree in advance on the value of the goods to be used as the basis for determining the freight charges and also to serve as the maximum liability of the carrier. Though once subject to common-law limits, and now confined by regulatory commissions, this doctrine at one point meant that a $\$ 15,000.00$ shipment could be valued at $\$ 50.00$ with the effect that a carrier could shift all but a nominal part of his liability to the shipper. This valuation method of limiting a carrier's liability has been used in other contractual relationships where courts have held that one party cannot avoid negligence liability by contract. ${ }^{70}$ The doctrine appears to have its origin in 1769 when one Gibbon hid a nail bag full of money in a load of hay and sent it on to London in Paynton's carriage. ${ }^{71}$ It was held that the shipper would be estopped from claiming the full amount of the loss because he had notice of the fact that the carrier's charges were graduated according to the value of the goods shipped and that it was a fraud for the shipper to attempt to avoid that excess charge.

Except for minor details ${ }^{72}$ most American courts did not deny the validity of this method of avoiding impositions. In this form it was an application of the doctrine of estoppel; the shipper would not be heard to value goods at their true value after loss when he misrepresented their value for freight charge purposes. ${ }^{73}$ In order to create an estoppel there would have to be a misrepresenta-

${ }^{67}$ Bradley must have known of the inaccuracy of his premise. Both he and the Court seem to have been well aware of the historic rationale for the doctrine of insurer liability. See quotation in text at note 62 supra; Express Co. v. Caldwell, 21 Wall. (U.S.) 264, 267 (1874).

${ }^{68}$ Consult discussion at 316-17 supra.

${ }^{69}$ For a somewhat different analysis consult Willis, The Right of Bailees to Contract Against Liability for Negligence, 20 Harv. L. Rev. 297 (1907).

70 E.g., warehouses, fur coat storage, parking lots, parcel checkrooms and telegraphs.

71 Gibbon v. Paynton, 4 Burr. 2299 (K.B., 1769).

72 Mostly relating to the question whether or not the carrier had an obligation to inquire as to value.

73 The leading case was Graves v. Lake Shore \& M. So. R. Co., 137 Mass, 33 (1884). See also cases cited note 76 infra. 
tion of the value which would mean that the carrier must be ignorant of the true value when he accepted the shipment. Also, there would have to be a gradation in rates according to the value of the goods else there would be no reliance by the carrier on the declared value. However, if these conditions were met the difference between the true value and the declared value would be irrelevant to the raising of an estoppel.

Some American courts upheld valuation as a limit on liability by use of a theory similar to that of liquidated damages, and subject to the same sort of restrictions. ${ }^{74}$ Most important, there must not be too great a disparity between the actual and the declared valuation or else the agreement would operate like a penalty and be invalid. ${ }^{75} \mathrm{~A}$ graduation of freight charges according to the value of the goods was unnecessary to the application of this doctrine.

The estoppel justification was more widely accepted in the various states, ${ }^{76}$ but there was reputable, if slight, authority for the liquidated damages view as well. ${ }^{77}$ There was also authority which allowed a limitation of liability by valuation without explaining its theory. ${ }^{78}$ And there were courts which refused to allow any sort of valuation theory on the simple ground that it invariably worked to frustrate the policy of the Lockwood case by shifting a substantial

74 The leading case was Moulton v. St. Paul, M. \& M. Ry. Co., 31 Minn. 85, 16 N.W. 497 (1883), which suggested the theory in dicta. See also authority cited note 77 infra.

75 There are substantial differences between a limitation of liability and liquidated damages; for exampleliquidated damages are a pre-estimate of the damage and in the event of the breach are the amount recovered, whereas a limitation of liability is only a maximum limit of recovery. Further, a limitation of liability cannot act in terrorum. Accordingly, both 3 Williston, Contracts $\$ 781 \mathrm{~A}$ (rev. ed., 1936), and the Rest., Contracts $\$ 339$, Comment $\mathrm{g}$ (1932), take the position that there does not have to be a great similarity between the actual damages and the limitation figure. As the Restatement notes, however, this does not apply to "certain public service contracts" and the cases support the exception, e.g., Moulton v. St. Paul, M. \& M. Ry. Co., 31 Minn. 85, 16 N.W. 497 (1883). It is hard for the uninitiated to see any real distinction between the "dominant" party's use of liquidated damages to impose threat of damages far in excess of his actual loss, or his use of limitation of liability to put the maximum recovery far below the "lesser" party's probable loss. Compare 3 Willison, Contracts $\$ 780$ (xev. ed., 1936): "But experience has shown that dangerous advantage is likely to be taken of a party to a contract if he is allowed to stipulate in advance as part of the contract that he will pay damages of any amount which the agreement may name, if he breaks the contract. It matters not that the parties have in terms agreed that an excessive sum, known by them to be excessive, shall be paid as damages. The sum is a penalty and payment of it will not be enforced."

${ }^{76}$ Brehme v. Adams' Express Co., 25 Md. 328 (1866); Muser v. American Express Co., 1 Fed. 382 (S.D.N.Y., 1880); cf. Unnevehr v. Steamship Hindoo, 1 Fed. 627 (S.D.N.Y., 1880); Graves v. Lake Shore \& M. So. R. Co., 137 Mass. 33 (1884). There was also considerable dicta supporting the estoppel doctrine, e.g., Cole v. Goodwin, 19 Wend. (N.Y.) 251 (1838); and Railroad Co. v. Lockwood, 17 Wall. (U.S.) 357 (1873).

77 South \& North Ala. R. Co. v. Henlein, 52 Ala. 606 (1875); Moulton v. St. Paul, M. \& M. Ry. Co., 31 Minn. 85, 16 N.W. 497 (1883). This theory was practically wortbless to the railroads since there had to be close correspondence between the actual value and the declared value.

${ }^{78}$ Squire v. New York Central R. Co., 98 Mass. 239 (1867), relied upon by Blatchford in Hart v. Pennsylvania R. Co., 112 U.S. 331 (1884); cf. Graves v. Lake Shore \& M. So. R. Co., 137 Mass. 33 (1884); Harvey v. Terre Haute \& I. R. Co., 74 Mo. 538 (1881). 
amount of the loss due to the carrier's negligence onto the shipper. ${ }^{79}$

Just eleven years after the Lockwood case the Supreme Court faced the question of the valuation doctrine in Hart v. Pennsylvamia $R$. Co. ${ }^{80}$ The plaintiff had shipped a load of race horses on the defendant railroad on a bill of lading that valued horses at $\$ 200.00$ per animal. One horse, allegedly worth $\$ 15,000.00$, was killed and several others injured by the admitted negligence of the railroad. The plaintiff was suing for the actual loss, the carrier defending on the ground that it was liable only to the extent of the declared value.

Plaintiff's counsel made the following points: (1) The value of the horses was much greater than the amount declared. (2) The carrier knew this fact when he received the animals for shipment. ${ }^{81}$ Counsel must have felt fairly confident of his case since these facts excluded any possibility of the liquidated damages theory and also prevented any estoppel. Accordingly, he spent most of his time arguing that the rule of the Lockwood case prevented partial as well as full avoidance of negligence liability by contract, a position which seems irrefutable. ${ }^{82}$

The Supreme Court, speaking through Justice Blatchford, did not see it that way. A valuation, "fairly entered into" was held to be a proper means of limiting the carrier's liability. The holding was apparently justified on both the estoppel and the liquidated damages theories, though this would appear to be a difficult thing to do. Thus at one point Blatchford said,

[A] limitation as to value ... exacts from the carrier the measure of care due to the value agreed on. The carrier is bound to respond in that value for negligence. The compensation for carriage is based on that value. The shipper is estopped from saying that the value is greater." $" 83$

And then he cited Gibbon v. Paynton ${ }^{84}$ to show that the principle of the decision was not new or novel, all of which indicates an estoppel theory. But later he observed that,

The subject matter of a contract may be valued, or the damages in case of a breach may be liquidated in advance. In the present case, the plaintiff accepted the valuation as "just and reasonable." The bill of lading did not contain a valuation of all animals as a fixed sum for each, but a graduated valuation according to the nature of the ani-

79 Southern Express Co. v. Moon, 39 Miss. 822 (1863); U.S. Express Co. v. Backman, 28 Ohio St. 144 (1875); Kansas City, St. J., \& C. B. R. Co. v. Simpson, 30 Kan. 645, 2 Pac. 821 (1883); Chicago, St. I., \& N. O. R. Co. v. Abels, 60 Miss. 1017 (1883).

80112 U.S. 331,335 (1884).

81 Counsel may have been bluffing here, but the Supreme Court never denied the statement. The lower court opinion, 7 Fed. 630, 632 (E.D. Mo., 1881), implies that the carrier did not know the true value, and the court in Squire v. New York Central R. Co., 98 Mass. 239 (1867), so read the opinion.

82 Unless one is prepared to argue that the policy of the Lockwood case was to induce due care and that liability for a nominal sum is adequate to perform that function.

${ }^{83}$ Hart v. Pennsylvania R. Co., 112 U.S. 331, 340-41 (1884).

84 Consult discussion at 320 and 325 supra. 
mal. It does not appear that an unreasonable price would have been charged for a higher evaluation..$^{85}$

Which, of course, indicates the "liquidated damages" theory. But, as in the case of the estoppel theory, Blatchford did not offer any suggestions as to what the requisite elements for either or both of the theories were.

The trouble with the $B$ art case lies in the looseness of the ratio decidendi. ${ }^{86}$ Both the estoppel theory and the liquidated damages theory were consistent with the Lockwood holding in theory if not in effect. By refusing to discuss the requisites for either doctrine and by implying that the holding in the Hart case rested on both, Blatchford paved the way for the notion that this valuation device was as a matter of contract law consistent with the Lockwood holding. Though it seems perfectly clear that the Court did not intend to overrule the Lockwood decision, its decision undeniably had that effect. ${ }^{87}$

${ }^{85}$ Hart v. Pennsylvania R. Co., 112 U.S. 331, 341-42 (1882). The last sentence suggests a wholly different approach to the valuation device which has been accepted by modern commentators, e.g., The Significance of Comparative Bargaining Power in the Law of Exculpation, 37 Col. Rev. 248 (1937). The thrust of the theory is to avoid the stigma of inequality of bargaining power by giving the shipper (or generally, the lesser party) the option of sending goods at full liability or at a limited liability with a discount on the latter. This introduces an element of free choice, thus restoring the equality of bargaining power and permitting the traditional concept of inviolability of contracts to control. The theory is impeccable if it is assumed that inequality of bargaining power is the significant factor in determining the validity of an exculpatory clause. But even granting the premise, the theory raises new and difficult policy questions. If followed, the courts would be obliged to consider two questions of fact in every case. First, was the discount for shipping at a lower rate reasonable; that is, was the discount so large as to make it economically prohibitive to ship at full liability? Second, did the shipper have actual knowledge, or would a reasonable man have had knowledge, of the option? Since both of these are jury questions, a strict application of the theory would mean that no carrier or person similarly situated could rely on a limitation of liability. Any relaxation of the supervision over the option would (at least under the inequality-of-bargaining-power theory) in due course lead to avoidance of the rule against contracting out of negligence liability.

86 "The distinct ground of our decision in the case at bar is, that where a contract of the kind, signed by the shipper, is fairly made, agreeing on the valuation of the property carried, with the rate of freight based on the condition that the carrier assumes liability only to the extent of the agreed valuation, even in case of loss or damage by the negligence of the carrier, the contract will be upheld as a proper and lawful mode of securing a due proportion between the amount for which the carrier may be responsible and the freight he receives, and of protecting himself against extravagant and fanciful valuations." Hart v. Pennsylvania R. Co., 112 U.S. 331,343 (1884).

${ }^{87}$ If Railroad Co. v. Lockwood, 17 Wall. (U.S.) 357 (1873), and Hart v. Pennsylvania R. Co., 112 U.S. 331 (1884), are consistent, it is through their relationship to the English Railway and Canal Traffic Act, 17 \& 18 Vict., c. 31 (1854). In Lockwood Bradley proposed that the test for the validity of carrier's stipulations was whether or not they were "just and reasonable," the precise words of the English statute. Blatchford in the Hart case also talked about the "just and reasonable" standard and stated at one point that: "In Great Britain, a statute directs this test to be applied by the courts. The same rule is the proper one to be applied in this country, in the absence of any statute." Hart v. Pennsylvania R. Co., 112 U.S. 331, 342 (1884). In the Hart case Blatchford relied heavily on Squire v. New York Central R. Co., 98 Mass. 239 (1867), which cited several cases under the English statute which purportedly had held that an exemption from all liability for negligence was not just and reasonable and that a limitation of liability by valuation was. Actually the construction of the English statute proved 
In 1906 Congress moved into this muddled law by amending the Interstate Commerce Act to provide that a carrier would be liable to the shipper for "any loss caused by it . . . and no contract or receipt or regulation shall exempt such common carrier... from liability here imposed." posed to have overruled the looseness of the Hart doctrine and restricted the valuation device to true estoppel cases. That was the way the Interstate Commerce Commission interpreted it, ${ }^{89}$ but the Supreme Court in 1915 did not agree and found no difficulty in allowing a carrier to limit his liability to $\$ 50.00$ on a $\$ 15,000.00$ carload of automobiles, though the carrier knew what was in the railroad car. ${ }^{90}$

In due course, Congress amended the Act again, ${ }^{91}$ conceding to the Court the Hart doctrine, but limiting it by requiring that a carrier could use the valuation device to limit its liability on a particular type of goods only with the authorization of the Interstate Commerce Commission, which, of course, had power to set the rates on both the actual and "released" value shipments. Interestingly, the standard which the Commission supposedly applies to determine whether a particular commodity should have a "released" rate is very similar to the standards the courts use when considering the validity of liquidated damages. ${ }^{92}$

\section{III}

It seems reasonably clear that roughly from Mansfield through Blatchford the judges were dealing with the problem of a carrier's power to contract out of negligence liability in terms of result rather than explicit empirical justification or logical legal doctrine. Holt undoubtedly had a point in the danger of collusion with thieves-how good a point it is impossible for us to assess, but it must have had some meaning in the beginning of the eighteenth century. It may even have had meaning when Mansfield stamped his imprimatur on it; Cowen

far more intricate than the Massachusetts court's citations would indicate. Consult Boyle \& Waghorn, The Law Relating to Traffic on Railways and Canals (1901). In any event it seems likely that the fuzziness of the Hart decision can be explained in terms of the influence of the English statute.

8834 Stat. 595 (1906), 49 U.S.C.A. $\$ 20(11)$ (1951), commonly known as the Carmack amendment, a part of the larger Hepburn Act.

${ }^{89}$ In the Matter of Released Rates, 13 I.C.C. 550 (1908): "But it is of the highest importance to note that this limitation is not secured by contract or notice-the contract has no validity per se. It is only right that a carrier who has acted in good faith should be protected against the frauds and misrepresentations of the shipper, and the law accomplishes this througb the operation of the principle of estoppel." Ibid., at 554.

${ }^{90}$ Pierce Co. v. Wells Fargo \& Co., 236 U.S. 278 (1915). The way to this was paved by Adams Express Co. v. Croninger, 226 U.S. 491 (1913).

91 The first and second Cummin's amendments, 38 Stat. 1197, 39 Stat. 441 (1915-16), as amended, 49 U.S.C.A. $\$ 10(11)$ (1951). Consult, 1 Roberts, Federal Liabilities of Carriers $\$ \$ 355-38$ (2d ed., 1929).

92 Released Rates on Stone in the Southeast, 93 I.C.C. 90 (1924). For the modern application of the released-value rule see Arpaia and Jenson, Common Carrier Liability in the Atomic Age, 51 Mich. L. Rev. 1173 (1953). 
evidently thought so, and the comparative wildermess of his jurisdiction may well have justified him even as late as 1838 . But by the beginning of the nineteenth century the insurer doctrine had evidently outlived its justification in England. Fault was thought as a matter of natural justice to be a necessary ingredient of liability and, at least until the railroad appeared as the defendant, judges were mainly concerned with finding a way to lower the level of liability to those situations where negligence was present. Carriers, eager to cooperate, gave judges the notices, thus sparing the bench the distasteful task of overruling established doctrine. Then, quite suddenly, the emphasis was shifted with the emergence of the railroad. The new problem was a fight to maintain the fault level of liability.

The English had the aid of a statute; Parliament responded fairly promptly with the Railway and Canal Traffic Act of 1854. While it is simple to criticize the draftsmanship of that statute, it gave the judges a very easy way of avoiding the development of a new rationale for carrier's liability. By inviting the judges to strike down any contractual term limiting liability which seemed to them unjust and unreasonable the judges were given a license to declare results without reasons, and that is substantially what was done.

In this country, however, perhaps partially as a result of the federal system, the legislature was much slower in responding to the presence of the railroad, and as a result the judges had to make do as best they could. In holding in the Lockwood case that the carrier could not stipulate from liability for negligence the Court was responding to two pressures. First, the Court had to do something about the insurer doctrine-its rationale was plainly from the stage coach era. Perhaps foolishly, the Court followed the English, allowing the carrier to contract out of the extraordinary aspects of liability rather than repudiating the insurer liability doctrine. Second, the Court could not allow the carrier to lower the level of his liability below fault if for no other than political reasons. There were good reasons available; for example the Court could have said that because travel insurance was not generally available; the carrier, who could easily insure, ${ }^{93}$ should at least bear the risk of negligently caused loss or damage. The Court, however, did not do this or anything similar but, rather, simply declared a result without giving an analytically sound justification, doing, in other words, just what the English had done but without the benefit of a statute.

As far as carriers are concerned, the foregoing is all academic since the area is now almost entirely ruled by statute, but the common law as declared in the Lockwood case is by no means dead. Its modern vitality is a consequence of the fact that the rule that a common carrier cannot contract out of negligence liability is and was by far the most widely known instance of the invalidity of an exculpatory term. A judge dealing with an exculpatory term in some other context where the legislature has not intervened will try to relate the situation be-

${ }_{93}$ Phoenix Ins. Co. v. Erie \& Western Transportation Co., 117 U.S. 312 (1886). 
fore him to the familiar rule. He can, of course, distinguish his case on the facts from the carrier situation, but if he is accustomed to using the rhetoric of the old cases he will try to determine the policy reasons for the carrier rule and then see if they are applicable to the case before him. If the same policy reasons are present, he will hold the clause void; if not, he will uphold it on the theory that generally freedom of contract should prevail.

Ideally this is what a judge should do; but when he turns to the carrier cases to determine the policy behind the rule that a carrier cannot contract out of negligence liability, there is very little available with which to work. It is here that the inadequacy of the stated rationale of the carrier rule is crucial even today. All that has been and can be distilled from those cases is inequality of bargaining power and inducing carelessness, rhetoric which a judge, if pressed, can apply to almost any situation. Faced with this problem a judge has three alternatives: first, he can decide the case on other grounds; second, he can uphold the validity of the clause; and third, he can strike the clause down as "against public policy."

A judge who wishes to avoid the problems presented by an exculpatory clause by deciding the case on other grounds can probably find authority for doing so in three different ways: he can decide as a matter of law that the clause could not operate because it was not a part of the contract; he can hold as a matter of construction that the clause was not intended to free the defendant from liability for negligence; or he can hold as a matter of construction or law that the clause did not cover gross negligence, thus leaving the ultimate question of recovery to the jury.

A decision that the clause is not part of the contract ${ }^{94}$ is best exemplified by the "token" doctrine, now the accepted method of dealing with parcel check-

94 The English have another dodge which so far as can be discovered has not been used in this context by American courts. But see Zayenda v. Spain \& Spain Ltd., 109 N.Y.S. 2d 87 (S.Ct., 1951), aff'd 280 App. Div. 752, 113 N.X.S. 2d 115 (2d Dep't, 1952). It is essentially the "deviation" doctrine familiar to American admiralty courts (consult Robinson, Admiralty $\$ 75$ [1939]), that any limitation of liability in the contract of carriage will not bar a recovery if the loss or injury occurs when the carrier has without good cause deviated from the normal route, or, in other words, breached his contract of carriage. The English have expanded this both to land carriers and to non-carriers by holding that any loss occurring when the basic contract is being violated will bar reliance on any limitation of liability in that contract. Davies v. Collins, 172 L.T.R. 155 (C.A., 1945); Bontex Knitting Works, Ltd. v. St. John's Garage, 60 T.L.R. 253 (C.A., 1944). Application of the "deviation" doctrine to non-carrier situations seems to have its origin in the dissent of Lush, J., in Harris v. Great Western Ry. Co., 1 Q.B.D. 515, 517 (1876). It was apparently first so held in Lilley v. Doubleday, 7 Q.B.D. 510 (1881), where the defendant had said that he would store plaintiff's goods at one warehouse and instead placed them at another which subsequently burned down. The plaintiff had insurance but was unable to collect from the insurance company because the policy provided that the goods were to be stored at the first warehouse. It was held that the limitation of liability in the warehouse receipt would not bar a recovery from the warehouseman because of the defendant's breach of contract. The English are, however, careful to distinguish between breach of contract and the negligent performance of a contract. Consult Ashby v. Tolhurst, [1937] 2 K.B. 242; Gibaud v. Great Eastern Ry Co., [1921] 2 K.B. 426. See also, White v. John Warrick \& Co., Ltd., [1953] 1 All. E. Rep. 1021 (C.A.). For an example of confusion between the two, consult Express Co. v. Kountze Bros., 8 Wall. (U.S.) 342, 352-53 (1869). 
rooms, ${ }^{95}$ and to a lesser degree with parking lots ${ }^{96}$ and similar service bailments. ${ }^{97}$ The theory is that any limitation of liability contained on the token given to the customer when the goods are stored is not assented to by the customer because he quite reasonably could assume that the sole purpose of the token is to identify his particular parcel, car or other chattel..$^{98}$ This theory can be pressed

${ }^{95}$ Kergald v. Armstrong Transfer Exp. Co., 330 Mass. 254, 113 N.E. 2d 53 (1953); Allen v. Southern Pacific Co., 117 Utah 171, 213 P. 2d 667 (1950); Brown v. Hines, 213 Mo. App. 298, 249 S.W. 683 (1923); Denver Union Terminal Ry. Co. v. Cullinan, 72 Colo. 248, 210 Pac. 602 (1922); Lebkeucher v. Pennsylvania R. Co., 97 N.J.L. 112, 116 Atl. 323 (1922), aff'd on opinion below, 98 N.J.L. 271, 118 Atl. 926 (1922); Van Noy Interstate Co. v. Tucker, 125 Miss. 260, 87 So. 643 (1921); Lancaster v. Sanford, 225 S.W. 808 (Tex. Civ. App., 1920); and Dodge v. Nashville, C. \& St. I. Ry. Co., 142 Tenn. 20, 215 S.W. 274 (1919). In Oklahoma City Hotel Co.v. Levine, 189 Okla. 331, 116 P. 2d 997 (1941), the court held that a limitation of liability by a parcel checkroom was void as contrary to public policy, followed in Fisk $\mathrm{v}$. Bullard, 205 Okla. 502, 239 P. 2d 424 (1951).

The point that the rationale of the carrier cases does not explain the doctrine that a carrier cannot avoid negligence liability by contract is illustrated by the cases involving parcel checkrooms operated by railroads. Counsel for the plaintiff frequently urges that the railroad is a common carrier and therefore the rules about common carriers ought to be applied. The answer is always given that the railroad is not acting in its capacity as a common carrier, which, as a technical matter, is entirely true. It is also true, however, that the same baggage is involved and presumably the carrier ought to be just as careful of it. The bargaining power of a parcel checkroom in a railroad station is, at least in some senses, as great as that of any railroad route. The shortcomings of this analysis may partially explain the popularity of the "token" doctrine in the parcel checkroom area. Compare Terry v. Southern Ry., 81 S.C. 279, 62 S.E. 249 (1908).

${ }^{96}$ E.g., some recent cases, Parkrite Auto Park Inc. v. Badgett, 316 Ky. 630, 242 S.W. $2 d$ 630 (1951); McAshan v. Cavitt, 149 Tex. 147, 229 S.W. 2d 1016 (1950); Malone v. Santora, 135 Conn. 286, 64 A.2d 51 (1949); American Automobile Ins. Co. v. Dayton Parking Co., 82 Ohio App. 466, 79 N.E. 2d 687 (1947); Palotto v. Hanna Parking Garage Co., 68 N.E. 2d 170 (Ohio App., 1946); Agricultural Ins. Co. v. Constantine, 144 Ohio St. 275, 58 N.E. 2d 658 (1944); Kravitz v. Parking Service Co., 29 Ala. App. 523, 199 So. 727 (1940), aff'd 240 Ala. 467, 199 So. 731 (1940); Sandler v. Commonwealth Station Co., 307 Mass. 470, 30 N.E. 2d 389 (1940).

${ }^{97}$ Brummett v. City of Jackson, 211 Miss. 116, 51 So. 2d 52 (1951) (notice, bailment of airplane); Palace Laundry Dry Cleaning Co. v. Cole, 41 A. 2d 231 (Mun. App. D.C., 1945) (laundry).

${ }_{98}$ The theory is perhaps best expressed in the opinion of Mellish, L.J., in Parker v. South Eastern Ry. Co., 2 C.P.D. 416 (C.A., 1877). The leading American case is probably Healy v. New York Central \& Hudson R. Co., 138 N.Y. Supp. 287 (3d Dep't, 1912), approved by the Court of Appeals some years later in Klar v. H. \& M. Parcel Room, Inc., 296 N.Y. 1044, 73 N.E. 2d 912 (1947) (memorandum opinion). The contrary view has been expressed as: "A great number of contracts are made by the delivery by one of the contracting parties to the other of a document in a common form, stating the terms by which the person delivering it will enter into the proposed contract. If the form is accepted without objection by the person to whom it is tendered, this person is, as a general rule, bound by its contents, and his act amounts to an acceptance of the offer made to him, regardless of whether he reads the doctment, or otherwise informs himself of its contents." Cunningham v. Int. Comm. of Y.M.C.A., 51 Cal. App. 487, 490, 197 Pac. 140, 141 (1921). Accord: Gibaud v. Great Eastern Ry. Co., [1921] 2 K.B. 426; cf., I'Estrange v. F. Graucob, Itd., [1934] 2 K.B. 394, which distinguished between signed and unsigned unread "agreements," holding that where the unread printed form is signed the parties are bound by its terms absent fraud or misrepresentation. Accord: Silvestri v. South Orange Storage Corp., 14 N.J. Super. 205, 81 A. 2d 502 (1951). Misrepresentation has been generously defined. Consult Curtis v. Chemical Cleaning and Dyeing Co. 
where the bailee has made every sort of effort to bring the limitation of liability to the customer's attention, short of reading the token every time it is handed out. Most of the parcel checkroom cases are still in this stage, the majority of cases holding that the bailor must have actual notice of the limitation. ${ }^{99}$

Another less common "modification of contract" problem which has troubled some courts appears in connection with warehouse receipts. The difficulty arises where the warehouse accepts the goods for storage and shortly thereafter sends a receipt containing a limitation of liability. ${ }^{100}$ The problem is whether the bailor has or has not assented to this limitation. Some courts have said that the bailor has assented because he could have expected a receipt; ${ }^{101}$ others take the

[1951] 1 K.B. 805. In Chapelton v. Barry Urban District Council, [1940] 1 K.B. 532 (C.A.), the English court adopted the "token" theory with regard to the hire of beach chairs following the dictum in Parker v. South Eastern Ry., supra. Accord: Richardson Spence \& Co. v. Rowntree, [1894] A.C. 217; Skrine v. Gould, 29 T.L.R. 19 (C.A., 1912). See also Denning, L.J., in Olley v. Marlborough Court, Ltd., [1949] 1 K.B. 532 (C.A.). The token theory has been viewed as a part of the larger "fine print" doctrine. Consult Contract Clauses in Fine Print, 63 Harv. L. Rev. 494 (1950).

${ }^{99}$ Cases cited notes 95,96 and 97 supra. The leading case going contrary to the actualnotice requirement is Noyes v. Hines, $220 \mathrm{Ill}$. App. 409 (1920), which held that a reasonable limitation of liability was valid if the parcel checkroom made all reasonable efforts to make the limitation known to its customers. The opinion suggests that the bailor might have expected some limitation in light of the very low tariff. This decision, correct under the English view (consult cases cited note 98 supra), has been approved in the reviews: Validity of an Ordinary Bailment Contract Limiting Liability of Bailee for Negligence, $86 \mathrm{U}$. of Pa. L. Rev. 772 (1938); and Bailments for Mutual Benefit-Limitation of Bailee's Liability, 20 Iowa L. Rev. 680 (1935). See also Missouri Pacific R. Co. v. Fuqua, 150 Ark. 145, 233 S.W. 926 (1921), and the concurring opinion of Pratt, C.J., in Allen v. Southern Pacific Co., 117 Utah 171, 213 P. 2d 667 (1950). Compare Denver Union Terminal v. Cullinan, 72 Colo. 248, 210 Pac. 602 (1922).

${ }^{100}$ The Uniform Warehouse Receipts Act, now in effect in every state, provides that a warehouseman cannot, "In any wise impair his obligation to exercise that degree of care in the safe-keeping of the goods entrusted to him which a reasonably careful man would exercise in regard to similar goods of his own." 3 U.L.A. $\$ 3(\mathrm{~b})$. This has generally been construed to prohibit direct exculpation from negligence liability, but not to invalidate the valuation method of limiting liability. Consult, e.g., George v. Bekins Van \& Storage Co., 33 Cal. 2d 834, 205 P. 2d 1037 (1949); Silvestri v. South Orange Storage Corp., 14 N.J. Supp. 205, 81 A. 2d 502 (1951). However, a limitation of Jiability by valuation is not good against conversion by the warehouseman, King Transfer \& Storage Co. v. Larson, 263 P. 2d 164 (Okla., 1953); Menuez v. Julius Kindermann \& Sons, Inc., 19 F. Supp. 7 (S.D. N.Y., 1937); Fidelity Storage Co. v. Kingsbury, 64 App. D.C. 208, 76 F. 2 d 978 (1935), modified on another point, 65 App. D.C. 69,79 F. $2 d 705$ (1935); Page v. Allison, 173 Okla. 205, 47 P. 2d 134 (1935); Arizona Storage \& Distributing Co. v. Rynning, 37 Ariz. 232, 293 Pac. 16 (1930). Compare cases cited note 131 infra. The influence of the carrier cases, particularly Hart v. Pennsylvania R. Co., 112 U.S. 331 (1884), is obvious here. One court had the temerity to insist that the valuation was not good if the warehouseman knew the true value of the goods, England v. Lyon Fireproof Storage Co., 94 Cal. App. 562, 271 Pac. 532 (1928), which is, of course, the estoppel doctrine. This decision was overruled in George v. Bekins Van \& Storage Co., supra. In Texas there is a statute (Vern. Civ. Stat. $\$ 5575$ [1925]) which has been construed to void the limitation of liability by valuation. Consult Mims v. Hearon, 248 S.W. 2d 754 (Tex. Civ. App., 1952), and Longwell Transfer v. Elliott, 267 S.W. 346 (Tex. Civ. App., 1924).

101 The best expression of this view is in Judge Rossman's dissent in Voyt v. Bekins Moving \& Storage Co., 169 Ore. 30, 127 P. 2d 360 (1942). See also Colgin v. Security Storage \& Van 
view that any variation of the implied contract has to be specifically assented to by the bailor, perhaps with new consideration. ${ }^{102}$

The influence of the carrier doctrine can only be inferred from these "modification of contract" cases on the theory that the courts would not be so technical if they were confident of the validity of the clause. However, the influence of the carrier cases can be directly observed in the second method of avoiding the exculpatory clause-by construing it not to cover negligence. The rule is usually phrased in terms of strict construction; in order to cover negligence the exculpation must be clear, almost express. ${ }^{103}$ In these terms the rule looks to be merely an application of the constructionary rule that instruments will be construed against the drafter, especially where it is a form contract, since invariably the exculpated party prepared the contract.

The cases, however, reveal that something more is involved, and this is well illustrated by the tug boat cases. ${ }^{104}$ The tug boat problem was first presented over a hundred years ago in a case in which the master of a tug presented to the tow captain a "permit" containing a clause to the effect that the towage service would be done "at the risk of the master and owners" of the tow. ${ }^{105}$ The trial court held that the tug was not a common carrier, but disregarded the clause and instructed the jury that the tug would be liable for want of ordinary care. The jury found for the plaintiff.

On appeal to the New York Supreme Court, the plaintiff's counsel strenuously urged: (1) that a tug was a common carrier and that consequently it could not contract out of negligence liability; (2) that even if it were not a common carrier the same limitation on its power to contract ought to be applied; and (3) that even if the tug could avoid negligence liability, as a matter of construction the clause did not free the tug from liability. The defendant argued with equal vigor that the tug was not a common carrier and that:

There is nothing ambiguous in the language. ... It admits of but one construction, which is, that the plaintiff's boat shall be towed at their entire risk. No exception is

Co., 17 So. 2 d 478 (C.A. La., 1944), rev'd on appeal, 208 La. 173, 23 So. 2 d 36 (1945); Central Storage Warehouse Co. v. Pickering, 114 Ohio St. 76, 151 N.E. 39 (1926). This position was approved in Contract Clauses in Fine Print, 63 Harv. L. Rev. 494 (1950), and is apparently the English position. Consult Clement Shaw \& Co., Ltd. v. Joseph C. Mount \& Co., 82 Ll.L.L. Rep. 995 (K.B., 1949).

${ }^{102}$ The most exhaustive expression of this view is in the majority opinion in Voyt v. Bekins Moving \& Storage Co., 169 Ore. 30, 127 P. 2d 360 (1942). Accord: Abend v. Haberman, 281 App. Div. 262, 119 N.Y.S. 2d 488 (1st Dep't, 1953) (fur coat storage). Warehousemen have figured a way around this doctrine: the customer is asked to sign a "work order" when the goods are delivered (and when he is least likely to read it) which contains the limitation clause. Consult Page v. Ace Van \& Storage Co., 87 Cal. App. 2d 294, 196 P. 2d 816 (1948).

1036 Williston, Contracts $\$ \S 1751 \mathrm{~B}, 1825$ (1936); Validity of Contractual Provision ... for Exemption from . . . Consequences of Own Negligence, 175 A.L.R. 8 (1948).

104 Consult generally Robinson, Admiralty $\$ 91$, p. 670 (1939); 1 Benedict, Admiralty $\S 100$ (Knauth ed., 1940).

${ }^{105}$ Alexander v. Greene, 3 Hill (N.Y.) 9 (S. Ct., 1842). The lower court opinion is not reported. 
expressed; and none can be inserted by construction, without imposing upon the parties a contract which they never designed to make. Assuming, moreover, that the parties knew the law and contracted in reference to it, then they knew that the defendants were not common carriers, nor responsible as such: and possessing this knowledge, what could they have meant by the term "risk" in the permit? Clearly, nothing less than risk arising from an omission of ordinary care; for otherwise the term would be senseless, and without a subject matter upon which it could operate. ${ }^{106}$

The court, Bronson, J., agreed with defense counsel both that a tug was not a common carrier and that the clause did cover negligence. ${ }^{107}$

In those days New York had its curious Court of Errors made up of the senate of the legislature. ${ }^{108}$ The case was appealed to that court ${ }^{109}$ but because only a few members delivered opinions, ${ }^{110}$ and none of these purported to present the view of the court, it is difficult, if not impossible, to tell the grounds for the court's decision. ${ }^{111}$ Bronson, defending the judgment of the Supreme Court, persisted in his view, but the senators reversed apparently on the ground that while the clause did cover negligence, it did not exculpate the defendant from liability for gross negligence. ${ }^{112}$ Although it is not perfectly clear, these judges would probably have said that the basis of their decision was not that public policy forbade a tug's avoiding negligence liability, but rather that the "at owner's risk" clause did not cover gross negligence as a matter of construing the

${ }^{105}$ Ibid., at 18. In Delaware \& Chesapeake Steam Towboat Co. v. Starrs, $69 \mathrm{~Pa} .36$ (1871) (towboat case), it was observed in answer to this argument that: "Nothing is more common than for men to express in their contracts and other writings that which would be the exact legal result if nothing had been said or written." Ibid., at 41.

${ }^{107}$ All of the early towboat cases follow this curious method of determining first whether or not the tug is a common carrier, and second, as a separate question, whether or not the tug can contract out of negligence liability. The same approach is used when a railroad is a defendant but acting in the capacity of a parcel checkroom or a landlord. It is a curious one-way street. If the court did find the defendant acting as a common carrier, then it would apply the rule that carriers cannot contract out of negligence liability. But if the court found that the defendant was not a common carrier, then it would still consider the issue of the validity of the clause. It seems clear that if there were an intelligible rationale for the rule that carriers cannot by contract avoid negligence liability the tug boat problem would have been handled as one rather than two questions.

${ }^{108}$ The court's full title was, Court of Impeachments and for the Correction of Errors. For a brief outline of its history consult, Scott, The Courts of the State of New York, 321-25, 393-96 (1909).

${ }^{109}$ Alexander v. Greene, 7 Hill (N.Y.) 533 (1844).

110 Eighteen senators voted, seventeen for reversal, one for affirmance, but only six delivered opinions.

111 Of the six opinions delivered, five declared that a tug ought to be considered a common carrier; one thought not, but thought that the clause did not cover gross negligence. However, when a senator requested a resolution declaring that the basis of the decision was that a tug was a common carrier, the senators refused to follow. In Wells v. Steam Navigation Co., 8 N.Y. 375, 381 (1853), Gardiner, J., states, "The court, by a formal vote, refused to declare defendants liable as common carriers. ..," but the reporter's note following Alexander v. Greene, 7 Hill (N.Y.) 533 (1844), says that the resolution was withdrawn, apparently without a vote.

112 It was so interpreted in Wells v. Steam Navigation Co., 8 N.Y. 375 (1853). 
clause to conform to the probable intention of the parties. ${ }^{113}$ In the same period the same problem was presented to a federal court in Pennsylvania which came to the opposite conclusion. ${ }^{114}$ The judge thought, though he reserved the question, that tugs ought to be considered common carriers; but even if not, he went on to comment that the stipulation was "repugnant to the spirit and purpose, as well as the body of the contract; and were such an interpretation claimed for the notice in this case, I could not regard it as otherwise than void." ${ }^{\prime 15}$

Twenty years later the same "at owner's risk" clause in a towage contract came before the Supreme Court in The Syracuse. ${ }^{116}$ Justice Davis said:

It is unnecessary to consider the evidence relating to the alleged contract of towage, because, if it be true, as the appellant says, that, by special agreement, the canal-boat was being towed at her own risk, nevertheless, the steamer is liable, if, through the negligence of those in charge of her, the canal-boat has suffered loss. Although the policy of the law has not imposed on the towing boat the obligation resting on a common carrier, it does require on the part of the persons engaged in her management, the exercise of reasonable care, caution, and maritime skill, and if these are neglected, and disaster occurs, the towing boat must be visited with the consequences. It is admitted in argument, and proved by the evidence, that the canal-boat was not to blame, and the inquiry, therefore, is, was the steamer equally without fault? ${ }^{117}$

This is perhaps the most dramatic example of the ambiguity which is typical of exculpatory law: Was Davis holding this clause void as "against public policy," or was he merely construing the contract not to cover negligence? The circuits split fifty years after The Syracuse, but it took the Supreme Court another thirty-five years to decide finally that it was a matter of public policy and not construction. ${ }^{118}$

In the early tug boat cases it was recognized that the "at owner's risk" clause

${ }^{113}$ Speaking of this case nine years later, Gould, $J$., said: "[I]t was there held tha' the words 'at the risk of the owner,' did not cover the proved acts of the agents of the defendant... . [T] ]he case holds that those defendants did not, not that they could not, protect themselves from liability in the case proved." Wells v. New York Central R. Co., 24 N.Y. 181, 185 (1862). And Smith, J., said: "The case ... holds . . . that negligence may be stipulated against ... but will not be deemed included in general words of exception unless expressly mentioned." Perkins v. New York Central R. Co., 24 N.Y. 196, 206 (1862).

114 Vanderslice v. Superior, 28 Fed. Cas. 970, No. 16,843 (E.D. Pa., 1850).

${ }^{115}$ Ibid., at 972.

11612 Wall. (U.S.) 167 (1870).

${ }^{117}$ Ibid., at 171.

118 The second circuit in The Oceanica, 170 Fed. 893 (C.A. 2d, 1909), interpreted The Syracuse as holding that the clause did not cover negligence as a matter of interpretation. The cases preceding this had generally been ambiguous, e.g., Ulrich v. Sunbeam, 24 Fed. Cas. 515, No. 14,329 (D.C. N.J., 1878). A few district courts from other districts followed The Oceanica, e.g., The Pacific Maru, 8 F. 2d 166 (S.D. Ga., 1925). The ninth circuit was the principal opposition, contending that The Syracuse stood for the proposition that all such exculpatory efforts by tugs were void as a matter of public policy. Mylroie v. British Columbia Mills Tug \& Barge Co., 268 Fed. 449 (C.A. 9th, 1920). That case was appealed to the Supreme Court, 259 U.S. 1 (1922), but Chief Justice Taft very carefully avoided clearing up the problem by 
might have been put into the contract to inform the tow that the tug would not be subject to the extraordinary liability of a common carrier, but only for negligence as an ordinary bailee for hire.119 This was a legitimate construction until it was determined that a tug was not a common carrier. ${ }^{120}$ Thereafter, however, since the tug was liable only for losses due to its own negligence, if the "at owner's risk" clause did not cover negligence it was meaningless. Yet the courts continued so to hold, as they have done in many of the other relationships where exculpation from negligence liability is common. ${ }^{21}$ The English have had no

construing the clause not to present the issue. Some years later the Court had another opportunity to settle the question in The Wash Gray, 277 U.S. 66 (1928), but only managed to perpetuate the confusion by quoting the language from The Syracuse as the basis for its decision. Matters were further muddled in Sun Oil Co. v. Dalzell Towing Co., 287 U.S. 291 (1932), by the Court distinctly upholding the validity of a pilotage clause providing that if the captain of the tug should act as pilot on the tow when the tow was under its own power, then the captain and the tug should be considered servants of the tow and accordingly not liable for negligence. Finally the matter was settled in Bisso v. Inland Waterways Corp., 349 U.S. 85 (1955), holding that the "all risks" clause was void as against public policy.

${ }^{119}$ The point was made by Senator Bockee in Alexander v. Greene, 7 Hill (N.Y.) 533 (1844), but most lucidly by Mason, J., in Wells v. Steam Navigation Co., 8 N.Y. 375 (1853), "In this contract, nothing is said about negligence. The parties, undoubtedly, had reference to those perils of navigation which were not the result of the contractor's own negligence. . . . It was, undoubtedly, well known to those engaged in this kind of navigation, that the law governing the liabilities of towing companies was not definitely settled. In some of the states, they were held liable as common carriers, while in one of our courts, a contrary doctrine was held; but the law was regarded as unsettled. And if the rule in relation to common carriers was to prevail, there would be a large class of risks peculiar to carriers, not arising from negligence, to which the defendants might, but for a special contract, have become liable, and it is quite reasonable to suppose, that the parties would make some special provision in relation to the risk each should assume." Ibid., at 379-80. This point was relied upon in The Oceanica, 170 Fed. 893 (C.A. 2d, 1909). Compare Ashmore v. Pennsylvania Steam Towing \& Transportation Co., 28 N.J.L. 180 (1860). Consult Olley v. Marlborough Court Ltd., [1949] 1 K.B. 532 (C.A., 1948), which involved a similar factual ambiguity as to whether the defendant was liable only for negligence or as an innkeeper and therefore as an "insurer." See also Joseph Travers \& Sons, Ltd. v. Cooper, [1915] 1 K.B. 73 (C.A., 1914).

${ }_{120}$ Despite the dicta in The Syracuse, quoted in text at 336 supra, the case generally cited as establishing that a tug is not a common carrier is The "Margaret," 94 U.S. 494 (1876). Note, however, that in a footnote to the quote in note 119 supra, Mason, J., said in 1853, "It seems to be pretty well settled, at the present date, that the owners of a steam tug boat are not common carriers, with respect to the vessel towed."

${ }^{121}$ The following clauses were held not to include negligently caused losses, although that was the extent of the exculpated party's liability: "The party of the second part will bear the expense of all losses through fires, theft and collision to said motor vehicle and [defendant] is not responsible for any of the above said losses. . . " Hill v. Carolina Freight Carriers Corp., 235 N.C. 705, 706, 71 S.E. 2 d 133, 134 (1952) (lease of a truck tractor); " $T$ further agree you will not be held responsible . . . in case of loss or damage by fire, theft, or loss of any kind beyond your control" held not to exculpate for negligently caused fires in contract to store and repair airplane, Revenue Aero Club, Inc. v. Alexandria Airport, Inc., 192 Va. 231, 232, 64 S.E. 2d 671, 673 (1951); "[A]ll . . equipment . . . at second parties risk, cost and expense. ..." Standard Insurance Co. of N.Y. v. Ashland Oil and Refining Co., 186 F. 2d 44 (C.A. 10th, 1950) (indemnity contract); "The Lessee covenants ... [to] render the Lessor harmless from any claims for loss or damage from fire, theft, or leakage. . . ." was held not to "extend ... to include a fire caused by dangerous affirmative acts [use of an acetylene torch] in which 
difficulty with this point; they are aware of the fact that an "at owner's risk" clause can have different meanings depending on whether the person before them is liable as an insurer or only for negligence. ${ }^{122}$

This interpretation of "all risks" or similar clauses not to cover negligence has troubled the commentators, ${ }^{123}$ and the point has been made before that it

the landlord has acquiesced." Nashua Gummed \& Coated Paper Co. v. Noyes Buick Co., 93 N.H. 348, 351, 41 A. 2d 920, 922 (1945); "Not responsible for loss in case of fire or theft." Langford v. Nevin, 117 Tex. 130, 298 S.W. 536 (1927) (parking lot); where lease of a store provided that the landlord could add stories to the building "without consent of the [tenant], and without any claim from it. ..." it was held that this "only waive[d] the right of claim for damages resulting from the proper construction of the building, and not claim for damages because of negligence in the construction," Mortrude v. Martin, 185 Iowa 1319, 1330, 172 N.W. 17, 21 (1919).

For some other recent examples consult Margoshes v. Reo Stores, Inc., 203 Misc. 588, 123 N.Y.S. 2d 602 (2d Dep't, 1953); Chicago \& N.W. Ry. Co. v. Chicago Packaged Fuel Co., 195 F. 2d 467 (C.A. 7th, 1952); Howard v. Handler Bros. \& Winell, Inc., 107 N.Y.S. 2d 749 (App. Div., 1951), aff'd without opinion, 303 N.Y. 990, 106 N.E. 2d 67 (1952); Rappaport v. Phil Gottlieb-Sattler, Inc., 280 App. Div. 424, 114 N.Y.S. 2d 221 (1st Dep't, 1952); (compare with these last two, Blinder v. United States Fire Ins. Co. of N.Y., 103 F.Supp. 902 [N.D. III., 1952]); Taccetta v. Chauncey Rice \& Rogovin, Inc., 75 F.Supp. 373 (S.D. N.Y., 1947); Otis Elevator Co. v. Maryland Casualty Co., 95 Colo. 99, 33 P. 2d 974 (1934).

Note the interesting statement in Wendt v. Sley System Garages, 124 Pa.Super. 224, 188 Atl. 624 (1936), that a parking lot which had posted a notice "Not responsible for fire or theft" had the effect that "under the facts and the law, the bailee was relieved of liability as an insurer, but not for loss due to its negligence." (Italics added.) Tbid., at 225, 228, 624, 625.

${ }^{122}$ As Bankes, L.J., said: "A common carrier is liable for the acts of his servants whether they are negligent or not; an ordinary bailee is not liable for the acts of his servants unless they are negligent. If a common carrier would protect himself from responsibility for all acts of his servants he must use words which will include those acts which are negligent; because words which would suffice to protect him from liability for acts properly done by his servants in the course of their service may fall short of protecting him from their negligent acts. But if an ordinary bailee uses words applicable to the acts of his servants, inasmuch as he is not liable for their acts unless negligent, the words will generally cover negligent acts, although such acts are not specially mentioned, because otherwise the words would have no effect." Rutter v. Palmer, [1922] 2 K.B. 87, 90 (C.A.). (The case involved a contract to sell the plaintiff's car. The contract provided that demonstration drives were at the owner's sole risk and this was held to exculpate the defendant from liability for an employee's negligent damage to the car.) Accord: Halbauer v. Brighton Corp., [1954] 2 All E.R. 707 (C.A.); Alderslade v. Hendon Laundry, Ltd., [1945] 1 K.B. 189. Compare Olley v. Marlborough Court Ltd., [1949] 1 K.B. 532 (C.A., 1948) (innkeeper); and note the almost contra decision in White v. John Warrick \& Co., Ltd., [1953] 2 All E.R. 1021 (C.A.). Cf. Dock Services Itd. v. Caledonia Stevedoring Co., Ltd., 82 Ll.L.Rep. 179 (K.B., 1948), and see D. H. Broad, Itd. v. General Accident Fire and Life Ass. Co., Ltd., [1951] 2 Il.L. Rep. 295 (C.A.).

${ }^{123}$ E.g., Professor Llewellyn, "[I]n the main we have our interference [in contracts] case by case. And in the main it moves by way of 'construing' the particular language in question not to have intended the result it did intend. . . . This procedure saves the lesser bargainor for the moment and salves the court's conscience both as to justice and policy. . . . Such 'construction' kills security in transactions, if 'security' means predictability of actions at law. No man is safe when language is to be read in the teeth of its intent. . . . For such 'construction' often defeats itself. It begins by admitting power in the parties (in the dominant party) to make their dicker as they wish. Sooner or later that admission will be taken seriously; sooner or later men will be held to the very type of thing which prior courts have conceived as too outrageous to be admitted as intent." What Price Contract-An Essay in Perspective, 40 Yale L.J. 704, 
is justified only when the exculpated party would, absent a limitation of liability, be liable for something more than negligence. ${ }^{124}$ American courts seem unimpressed. ${ }^{125}$ The interpretation that "all risks" does not include negligence perhaps had more justification in an earlier day-judges of that period indicated that contracting out of negligence liability was in some way morally reprehensible. It was so shocking that it was not to be assumed that the parties intended that result, even if the literal language of the contract would seem to compel it. ${ }^{126}$ That sort of approach can no longer be accepted. Insurance, particularly the automobile liability policy, has made modern society's approach to the accident problem totally different. A certain number of accidents are now thought to be inevitable. Human frailty is as readily reduced to statistics as the possibility of fire or other "inevitable accident." To say that loss or damage due to negligence is any less a "risk" than fire loss is probably not the attitude of the average man, certainly not the commercial man.

The third method by which a judge can avoid deciding the exculpatory question is by giving the problem to the jury under an instruction to the effect that if it believes that the defendant was guilty of gross negligence it should find for the plaintiff regardless of the exculpatory clause. Ever since the early "notice" cases in England, ${ }^{127}$ judges have been talking about a contract relieving one party from liability for everything but gross negligence and wilful default, but rarely do they indicate in this context how gross negligence differs from ordinary negligence-if it does, ${ }^{128}$ or from wilful default-if it does. ${ }^{129} \mathrm{Nor}$, frequently, do the opinions indicate whether they are based on "public policy" or on construing the particular clause before them. The difficulty is further compounded by the fact that the pronouncement that a person cannot contract out of gross negligence is frequently in the form of dicta.

732 (1931). Consult also Llewellyn, Review of Prausnitz, 52 Harv. L. Rev. 700 (1939). It should be noted that these remarks do not go to "modification" approaches to exculpatory clauses.

124 E.g., Validity of an Ordinary Bailment Contract Limiting Liability of Bailee for Negligence, $86 \mathrm{U}$. of Pa. L. Rev. 772 (1938).

${ }^{125}$ But consult Miller's Mutual Fire Insurance Ass'n v. Parker, 234 N.C. 20, 65 S.E. 2d 341 (1951); Blinder v. United States Fire Insurance Co. of N.Y., 103 F.Supp. 902 (N.D. IIl., 1952).

126 "It would require a man of a good deal of effrontery to ask another to insert in his contract for performing a service, a clause permitting him to be negligent in its performance, and relieving him from all liability for the injuries which his gross negligence might occasion; and the man who would insert such a clause in the contract would be a fit subject for a committee to take charge of his person and property." Mason, J., in Wells v. Steam Navigation Co., 8 N.Y. 375, 380 (1853). For a similar though more restrained outburst, see Denning, L.J., in Alder v. Dickson, [1954] 2 Ll.L. Rep. 267 (C.A.).

${ }^{127}$ Discussed at 320-22 supra.

${ }^{128}$ It eventually did not in the notice cases. Consult note 40 supra.

${ }^{129} \mathrm{It}$ does not for some courts today. Consult, e.g., Brady v. Glosson, 87 Ga.App. 476, 74 S.E. $2 d 253$ (1953). 
There is no question that the concept of degrees of negligence was introduced into the common law in Lord Holt's elaborate opinion in Coggs v. Bernard..$^{130}$ It is far more difficult to determine the derivation of the doctrine that contracting out of gross negligence cannot be done either as a matter of construction or of public policy. ${ }^{131}$ Probably the first ruling of that nature was in the early "notice" cases simply because that was the first time exculpation was extensively practiced, but no substantial evidence has been found indicating that the concept spread from those cases into all the various situations in which it now can be found. ${ }^{132}$

Story suggested that the gross-negligence-avoids-the-contract doctrine may have come from the notion that gross negligence was the equivalent of fraud, ${ }^{133}$ and from that to the familiar rule that a person cannot by contract avoid the consequences of his own frauds. ${ }^{134}$ Insofar as this thesis was based on the early "notice" cases, ${ }^{135}$ Story was setting up a straw man because those cases contain

1302 Ld. Raym. 909 (1703).

${ }^{131}$ There is some authority to the contrary, e.g., Donlon Bros. v. Southern Pacific Co., 151 Cal. 763, 91 Pac. 603 (1907). There is also a line of cases holding that a limitation of liability by valuation under the Interstate Commerce Act will protect the carrier against conversion of goods by his employees. This is on the theory that "the conversion doctrine is pertinent only when there has been a true conversion, i.e. where the carrier has appropriated the property for its own use or gain. The carrier may properly limit its liability where the conversion is by third parties or even by its own employees. In the latter circumstance, while the carrier may have been guilty of negligence in the selection of its employees, it has not been unjustly enriched, nor has it been guilty of any misconduct." Glickfeld v. Howard Van Lines, Inc., 213 F. 2d 723, 727 (C.A. 9th, 1954). Accord: Normann v. Burnham's Van Service, 73 So. 2d 640 (La. C.A., 1954); VanDyke v. Pennsylvania R. Co., 46 Del. 529, 86 A. 2d 346 (1952); Railway Express Agency, Inc. v. Marchant Calculating Mach. Co., 52 A. 2d 277 (Mun. App. D.C., 1947); Illinois Central R. Co. v. Fontaine, 217 Ky. 211, 289 S.W. 263 (1926); Henderson v. Wells Fargo \& Co. Exp., 217 S.W. 962 (Tex. Civ. App., 1920); Moore v. Duncan, 237 Fed. 780 (C.A. 6th, 1916); D'Utassy v. Barrett, 219 N.X. 420, 114 N.E. 786 (1916). Contra: F. A. Straus \& Co. v. Canadian Pac. Ry. Co., 134 Misc. 439, 234 N.X.Supp. 622 (S. Ct., 1929); P. W. Sands v. American Ry. Express Co., 154 Minn. 308, 197 N.W. 721 (1923); Fessler v. Detroit Taxicab \& Transfer Co., 204 Mich. 694, 171 N.W. 360 (1919); Heuman v. Powers Co., 226 N.Y. 205, 123 N.E. 373 (1919). Compare cases cited note 100 supra.

${ }_{132}$ E.g., some recent cases, Thomas v. Atlantic Coast Line R. Co., 201 F. 2 d 167 (C.A. 5th, 1953) (spur line lease, indemnity contract); Brady v. Glosson, 87 Ga.App. 476, 74 S.E. $2 d$ 253 (1953) (lease); Santoro v. Central N.Y. Power Corp., 189 Misc. 567, 72 N.Y.S. 2d 12 (S. Ct., 1947) (electric service contract, clause in filed tariff schedule); Barclay, Inc. v. Maxfield, 48 A. 2d 768 (Mun. App. D.C., 1946) (bailment, clause in lease); Fairfax Gas \& Supply Co. v. Hadary, 151 F. 2d 939 (C.A. 4th, 1945) (supplier of compressed gas for home use). Some of these cases contain only dicta to the effect that an exculpatory clause does not or cannot cover gross negligence.

${ }^{133}$ Story, Bailments $\$ 19$ (9th ed., Schouler, 1878). Story evidently got the idea from Sir W. Jones, Essay on Bailments. Consult also Holmes' note in 2 Kent, Commentaries $562 \mathrm{n}$. $\mathrm{b}$ (12th ed., Holmes, 1873).

${ }^{134}$ Story, Bailments $\$ 32$ (9th ed., Schouler, 1878).

${ }^{135}$ Story never implied this, but they would appear to be the only cases raising the point at that time. The cases are discussed at 320-22 infra. Story's discussion of them can be found ibid., at $\S \S 549,570-71$. 
no hint that that is what the judges thought they were doing. ${ }^{136}$

The tug boat cases are revealing in this connection. There is mention of gross negligence in some of the early state cases where the issue was given to the jury, ${ }^{137}$ but in cases before the federal courts sitting in admiralty, no reference to the doctrine is found. Of course, most of these courts were saying that a tug could not contract out of negligence liability, ${ }^{138}$ but the fact that the phrase does not appear in the opinions of courts that were upholding the exculpation indicates that the gross-negligence-avoids-the-contract doctrine ${ }^{139}$ is basically a means of giving to a jury cases in which the courts would otherwise have to decide for the plaintiff as a matter of law.

Most of the law of exculpation is in these three avoiding-the-problem areas of modification, construction and gross negligence. Only rarely do the courts deal directly with the validity of the clause itself. Where they have done so, there are relatively few situations, hardly any in bailments, ${ }^{140}$ where an exculpatory clause covering negligence has been held valid. The commentators of the early 19 th century, particularly Justice Story, ${ }^{141}$ were quite confident that bailees generally could avoid negligence liability by contract, and Story's influence probably accounts for the number of miscellaneous bailment and other cases of that period and subsequently which have upheld exculpatory efforts. ${ }^{142}$

136 "In respect to gross negligence, it is often said that it is equivalent to fraud, and is evidence of fraud. That it may, in certain cases, afford a presumption of fraud, and, indeed, that in very gross cases it may approach so near as to be almost undistinguishable from it, may be admitted, especially when the facts seem hardly consistent with honest intention. But that generally gross negligence and fraud are convertible terms, is a doctrine not supported by any just inference from the authorities in the common law." Ibid., $\$ 19$. Consult also $\$ \$ 20-23$.

137 E.g., Ashmore v. Pennsylvania Steam Towing \& Transportation Co., 28 N.J.L. 180 (1860); Wright v. Gaff, 6 Ind. 416 (1855); Wells v. Steam Navigation Co., 8 N.Y. 375 (1853); Alexander v. Greene, 7 Hill (N.Y.) 533 (1844).

138 Pages 334-36 supra.

${ }^{139}$ Compare note 94 supra.

140 Consult, Validity of an Ordinary Bailment Contract Limiting Liability of Bailee for Negligence, $86 \mathrm{U}$. of Pa. L. Rev. 772 (1938).

${ }^{141}$ Story, Bailments $\$ 32$ (9th ed., Schouler, 1878).

142 E.g., some recent cases, Insurance Co. of North America v. Elgin, J. \& E. Ry. Co., 229 F. 2d 705 (C.A. 7th, 1956) (lease of equipment); Fire Ass'n of Philadelphia v. Allis Chalmers Mfg. Co., 129 F.Supp. 335 (N.D. Iowa, 1955) (installation of electrical equipment); MICTighe v. N. E. Tel. \& Tel. Co., 216 F. 2d 26 (C.A. 2d, 1954) (failure to include name in telephone book); Palmquist v. Mercer, 263 P. 2d 341 (Cal. App., 1954), modified, 43 Cal. 2d 92, 272 P. 2d 26 (1954) (riding stable); Shafer v. Reo Motors, Inc., 108 F.Supp. 659 (W.D. Pa., 1952), aff'd, 205 F. 2d 685 (C.A. 3d, 1953) (sale of truck); Direct Transportation Co. v. Baltimore \& O. R. Co., 96 Ohio App. 204, 121 N.E. 2d 565 (1953) (contract to haul freight between depots); Oregon Portland Cement Co. v. E. I. Du Pont De Nemours \& Co., 118 F.Supp. 603 (D.C. Ore., 1953) (blasting contract); Maryland Casualty Co. v. Owens-Illinois Glass Co., 116 F.Supp. 122 (S.D. W.Va., 1953) (bottling contract); Aluminum Co. of America v. Hully, 200 F. 2d 257 (C.A. 8th, 1952) (indemnity contract); Boll v. Sharp \& Dohme, Inc., 107 N.Y.S. 
Today the draftsman can be confident of the validity of an exculpatory clause only in the landlord-tenant relationship..$^{143}$ One of the reasons, although by no means the only one, for the success of exculpation in this area is that it was early decided that a railroad could exculpate itself from liability to its lessees on the right of way for damage caused by negligent operation of the railroad. ${ }^{144}$ After this holding it was difficult, though theoretically entirely possible, to convince any court that the landlord-tenant relationship was a fit subject for the common-carrier rule. ${ }^{145}$ If a railroad acting as lessor could exculpate itself, there was no obvious reason why landlords generally could not do so.

2d 174 (S. Ct., 1951) (blood donation); Philippine Air Lines, Inc. v. Texas Engineering \& Manufacturing Co., 181 F. 2d 923 (C.A. 5th, 1950) (airplane conversion contract); Standard Ins. Co. of N.Y. v. Ashland Oil \& Refining Co., 186 F. 2d 44 (C.A. 10th, 1950) (oil drilling contract); Paddle v. Atlantic Basin Iron Works, Inc., 91 N.Y.S. 2d 336 (S. Ct., 1949) (indemnity contract); Charles Lachman Co. v. Hercules Powder Co., 79 F.Supp. 206 (E.D. Pa., 1948) (sale of chemical cleaning compound). For earlier cases consult Validity of Contractual Provision ... for Exemption from... Consequences of own Negligence, 175 A.L.R. 8 (1948).

${ }^{143}$ Consult generally Rehberg, Exculpatory Clauses in Leases, 15 Ga. B. J. 389 (1953); Jones, An Exculpatory Provision That Will Protect the Lessor, Ins. I. J. 79 (1946). Only rarely does an exculpatory clause exonerating the tenant from liability get into court on the issue of its validity. Consult, e.g., General Mills, Inc. v. Goldman, 184 F. 2 d 359 (C.A. 8th, 1950), noted in 6 Vand. L. Rev. 408 (1953). In almost all states exculpation by landlords is permitted; the exceptions are by statute. For example, consult note 155 infra; Connecticut v. Manchester Amusement Co., 79 N.H. 450, 111 Atl. 339 (1920); Papakalos v. Shaka, 91 N.H. 265, 18 A. 2d 377 (1941); see also Nashua Gummed \& Coated Paper Co. v. Noyes Buick Co., 93 N.H. 348, 41 A. 2d 920 (1945), and possibly New Jersey, Kuzmiak v. Brookchester, Inc., 33 N.J.Super. 575, 111 A. 2d 425 (1955), apparently overruling Wade v. Park View Inc., 25 N.J.Super. 433, 96 A. 2 d 450 (1953).

Some recent cases supporting exculpation by a landlord include: Scheffer v. United States, 136 F.Supp. 931 (W.D. Pa., 1956); Plaza Hotel Co. v. Fine Products Co., 87 Ga.App. 460, 74 S.E. 2d 372 (1953); Jackson v. First Nat'l Bank of Lake Forest, 415 Ill. 453, 114 N.E. 2d 721 (1953), apparently overruling Arling v. Zeitz, 269 Ill.App. 562 (1933); and Cerny Pickas \& Co. v. C. R. Jahn Co., 347 Ill.App. 379, 106 N.E. 2d 828 (1952); Kansas City Stockyards Co. v. A. Reich \& Sons, Inc., 250 S.W. 2d 692 (Mo., 1952); Mackenzie v. Ryan, 230 Minn. 378, 41 N.W. 2d 878 (1950), following the leading case of Weirick v. Hamm Realty Co., 179 Minn. 25, 228 N.W. 175 (1929); Standard Ins. Co. of N.Y. v. Ashland Oil \& Refining Co , 186 F. $2 d$ 44 (C.A. 10th, 1950); Robinson v. Tate, 34 Tenn.App. 215, 236 S.W. 2 d 445 (1950); Werner v. Knoll, 89 Cal.App. 474, 201 P. $2 d 45$ (1949). Cases pointing in the other direction include, Kay v. Cain, 154 F. 2 d 305 (C.A.D.C., 1946) and Housing Authority of Birmingham Dist. v. Morris, 244 Ala. 557, 14 So. 2d 527 (1943).

${ }^{144}$ The first case so holding was Griswold v. Illinois Central Ry. Co., 90 Iowa 265, 57 N.W. 843 (1894). It was approved in Hartford Fire Ins. Co. v. Chicago, M. \& St. P. Ry. Co., 175 U.S. 91 (1899), where the Supreme Court held that the question was one of state rather than general law. Perhaps the most influential case was Checkley v. Illinois Central R. Co., 257 Ill. 491, 100 N.E. 942 (1913); others are collected in Validity of Contractual Provision . . . for Exemption from ... Consequences of own Negligence, 175 A.L.R. 8, 94-100 (1948).

${ }_{145}$ Fairly recent cases which specifically mention the carrier cases include, Commercial Union Assurance Co. v. Foley Bros., 141 Minn. 258, 169 N.W. 795 (1918); Cobb v. Gulf Refining Co., 284 Ky. 523, 145 S.W. 2d 96 (1940); Manius v. Housing Authority of the City of Pittsburgh, 350 Pa. 512, 39 A. 2d 614 (1944); Wade v. Park View, Inc., 25 N.J.Super. 433, 96 A. $2 d 450$ (1953). 
The Supreme Court of Iowa was the first to consider the question of a railroad's power to avoid liability to tenants on its right of way. ${ }^{146}$ On the first hearing of the case the court held the exculpatory covenant void as against public policy, basing its decision largely on two Iowa statutes. The first provided that common carriers could not contract out of negligence liability, and the second made railroads absolutely liable for fires started by locomotives. ${ }^{147} \mathrm{On}$ rehearing the court reversed itself. The first statute was eliminated by construing it not to apply to common carriers when they were acting in some other capacity, and the second on ground that the railroad had no duty toward the public for buildings on its own land. The court justified its decision as follows: [Both parties] knew that the defendant [railroad] ... might be negligent ... . [and] plaintiff [tenant] had an insurable interest, and could, as he did, protect himself, in part at least, against loss by either accident or negligence. The defendant had no insurable interest, and could only protect itself from the hazard by refusing consent, or by contracting for indemnity, which it did. ${ }^{148}$

\section{And later the court said:}

It seems to us now quite clear that, as these buildings could only be placed upon the defendant's right of way by its consent, and were so placed upon the premises, and on the conditions expressed in the lease, the public has no interest therein ... that would be injured by giving effect to the agreement in question. Much as the public may have been interested in the convenience of such a place of business, it has no interest as to who should carry the hazard incident to that property located as it was. ${ }^{149}$

146 Griswold v. Illinois Central Ry. Co., 53 N.W. 295 (Iowa, 1892), rev'd on rehearing, 90 Iowa 265,57 N.W. 843 (1894). The dissenting opinion on rehearing is substantially the same as the original majority opinion.

${ }^{147}$ The history of the statutes making railroads absolutely liable for fires started by the operation of locomotives is reviewed in St. Louis \& S. F. Ry. Co.v. Mathews, 165 U.S. 1 (1897).

${ }_{148}$ Griswold v. Illinois Central Ry. Co., 90 Iowa 265, 271, 57 N.W. 843, 845 (1894). It is believed that the court was wrong in its dictum about insurable interest although no contemporary authority directly to the contrary has been found. Probably the court was led astray by the history of the absolute liability statutes. In the first such statute (1837) the MFassachusetts legislature provided that: "Every railroad corporation shall be liable in damages to a person whose buildings or property may be injured by fire communicated by its locomotive engines, and shall bave an insurable interest in the property upon its route for which it may be so held liable, and may procure insurance thereon in its own behalf." Ann. Laws of MIass. (1948) c. $160 \$ 234$. The Iowa statute had no such provision for insurance by the railroad, Iowa Code (1954) $\S 479.126$, and this was probably what led the court to think that the railroad could not insure against the risk. Although, liability insurance was not as common then as it is today, it was known: for example, employer's liability policies. Consult, e.g., Employers' Liability Assurance Corp. v. Merrill, 155 Mass. 404, 29 N.E. 529 (1892), and, in the carrier contezt, insurance against liability in connection with the carriage of goods, consult, e.g., Phoenix Insurance Co. v. Erie \& Western Transportation Co., 117 U.S. 312 (1886). See also Eastern Railroad Co. v. Relief Fire Insurance Co., 98 Mass. 420 (1868). Other cases indicating that the railroad could probably have insured against the risk in Iowa may be found in Cooley, Briefs on Insurance 230, 247, 325 (2d ed., 1927).

149 Griswold v. Illinois Central Ry. Co., 90 Iowa 265, 272, 57 N.W. 843, 846 (1894). In some states by incorporating as a public warehouse access to the right of way could be obtained by eminent domain proceedings. Consult James Quirk Milling Co.v. Minneapolis \& St. L. R. Co., 98 Minn. 22, 107 N.W. 742 (1906). 
This was one of a number of decisions of the period which considered the impact of insurance on the law of exculpation. ${ }^{150}$ The thrust generally was toward pointing out that it was possible by way of insurance to contract for indemnity from liability for negligent conduct, thereby threatening the rationale that a person for a valuable consideration could not contract for immunity from negligence liability because it would induce carelessness. It is perhaps unfortunate that the landlord-tenant relationship had to bear the brunt of this insight. With commercial leases, which are of course what the railroad leases were, the question of who should pay the insurance could well be a matter for contract between the parties. With housing, particularly low income housing, it is perhaps not so clear. ${ }^{151}$ The terms of the average apartment lease are beyond mutation by individual tenants, and the prevalence of the form lease probably makes it difficult, if not impossible, to get significantly different terms by moving from one landlord to another within the same community. ${ }^{152}$ Considering the very minimal degree of liability to which the landlord is subject, ${ }^{153}$ tort liability which could not be avoided by contract might well be an inducement to landlords, particularly of low income housing, to perform their obligations to maintain and repair. ${ }^{154}$ Several states have voided exculpatory clauses in leases by statute, ${ }^{155}$ but as yet few courts have gone further than to intimate the possi-

${ }^{150}$ Others include Hartford Fire Insurance Co. v. Chicago M. \& St. P. R. Co., 175 U.S. 91 (1899); Phoenix Insurance Co. v. Erie \& Western Transportation Co., 117 U.S. 312 (1886), which contains the statement: "No rule of law or of public policy is violated by allowing a common carrier ... to have [goods] insured ... and to recover for any loss ... though occasioned by the negligence of his own servants. By obtaining insurance, he does not diminish his own responsibility to the owners of the goods, but rather increases his means of meeting that responsibility." Ibid., at 324. More recently when the Minnesota court was considering the same question presented in the Griswold v. Illinois Central Ry. Co., 90 Iowa 265, 57 N.W. 843 (1894), it was said that "since ... the risk is one against which a railroad company may properly procure indemnity, there is no reason why it may not procure the equivalent in the form of exemption from liability by direct contract with its lessee rather than by a separate contract for indemnity with an insurance company. ... "Petit Grain \& Potato Co. v. Northern Pacific Ry. Co., 227 Minn. 225, 242, 35 N.W. 2d 127, 136 (1948). See also Northern Pacific Ry. Co. v. Thornton Bros., Co., 206 Minn. 193, 288 N.W. 226 (1939). Other recent cases recognizing the importance of insurance in the law of exculpation include, Kansas City Stockyards Co. v. A. Reich \& Sons, Inc., 250 S.W. 2d 692 (Mo., 1952); Philippine Air Lines, Inc. v. Texas Engineering \& Manufacturing Co., 181 F. 2d 923 (C.A. 5th, 1950); Griffiths v. Henry Broderick, Inc., 27 Wash. 901, 182 P. 2d 18 (1947).

${ }^{151} \mathrm{~A}$ surprisingly large number of the cases involve commercial leases, relatively few housing. The commercial leases sometimes verge close to the line, e.g., dentists, small luxury shops and the like where the suggested distinction may be unusable.

${ }^{152}$ There is some evidence of this in the cases, e.g., Wade v. Park View, Inc., 25 N.J.Super. $433,96 \mathrm{~A} .2 \mathrm{~d} 450$ (1953), where the tenant signed the lease without reading it on the representation of the agent that it was the "ordinary apartment lease."

${ }^{153}$ The comparatively recent development of landlord liability is reviewed in 2 Powell, Real Property $\$ \S 238-39$ (1950). Most of the cases involve negligent failure to maintain common passageways.

${ }_{154}$ This was Cardozo's justification for giving tenants tort damages for the landlords' failure to obey the tenement law. Altz v. Leiberson, 233 N.Y. 16, 19, 134 N.E. 703, 704 (1922).

155 New York, Real Property Law (1937) c. 907 § 234; Massachusetts, Gen. Stat. (1945) c. $186 \S 15$. The history of landlord exculpation in New York is a good example of how bad law 
bility, ${ }^{156}$ and there has been little indication of a judicial recognition of the potentialities of the distinction between the commercial and the housing lease. ${ }^{157}$

Most of the decisions which have resulted in holding the exculpated party liable have done so sub rosa rather than by holding the clause void as against public policy. The modern trend, once the issue is faced, seems to be to hold exculpatory clauses void, and frequently that holding is combined with some very general language. ${ }^{158}$ The tendency to say that generally exculpatory efforts

can breed litigation. The trouble started in Worthington v. Parker, 11 Daily (N.Y.) 545 (1885), where it was held that a clause to the effect that the landlord would not be liable "for damages caused by elements, by leakages in roof or piping" did not cover a leak in a pipe caused by the negligence of the landlord. Ibid., at 561. This holding was repeated in Randolph v. Feist, 23 Misc. 650, 52 N.Y.Supp. 109 (S. Ct., 1898) and Eugene C. Lewis \& Co. v. Metropolitan Realty Co., 112 App.Div. 385, 98 N.Y.Supp. 391 (2d Dep't, 1906), but in Levin v. Habicht, 45 MIisc. 381, 90 N.Y.Supp. 349 (S. Ct., 1904), the problem was compounded by a holding that a clause specifically referring to negligence did not exculpate the landlord as a matter of construction. The Court of Appeals gave no help in Pratt, Hurst \& Co., Ltd. v. Tailer, 186 N.Y. 417, 79 N.E. 328 (1906), but in Dreschler Rothberg Co. v. Landeker, 140 N.Y.Supp. 1025 (S. Ct., 1913), Judge Lehman tried to straighten things out by establishing a distinction between affirmative negligence and passive negligence, holding exculpation valid as to the latter. This was repeated in Unterberg v. Israel, 103 Misc. 675, 171 N.Y.Supp. 133 (S. Ct., 1918), and the Court of Appeals approved the doctrine in Hirsch v. Radt, 228 N.Y. 100,126 N.E. 653 (1920). The doctrine was applied with increasing difficulty of definition in E. Candia \& Co. v. Rubin, 209 App.Div. 357, 204 N.Y.Supp. 590 (1st Dep't, 1924); Kessler v. The Ansonia, 222 App.Div. 148, 225 N.Y.Supp. 589 (1st Dep't, 1927), on retrial, 253 N.Y. 453, 171 N.E. 704 (1930); Lowy \& Feffer, Inc. v. Mor-Ro Realty Corp., 223 App.Div. 621, 229 N.Y.Supp. 169 (1st Dep't, 1928). Finally, in Kirshenbaum v. General Outdoor Advertising Co., 258 N.Y. 489,180 N.E. 245 (1932), it was said: "Stipulations between a landlord and a tenant, determining which shall bear a loss arising from non-repair or mis-repair of the tenement, and which shall be immune, are not matters of public concern. Moreover, the two stand upon equal terms, neither the one nor the other is under any form of compulsion to make the stipulations; either may equally well accept or refuse entry into the relationship of landlord and tenant." Ibid., at 495, 247. In 1937 the legislature settled the mess by making any such stipulations void as contrary to public policy.

${ }^{156}$ Consult note 143 supra.

${ }^{157}$ But see Kuzmiak v. Brookchester, Inc., 33 N.J.Super. 575, 111 A. $2 d 425$ (1954), and Jackson v. First Nat'l Bank of Lake Forest, 415 Ill. 453, 114 N.E. 2 d 721 (1953). In other areas of exculpatory law there is language in some of the cases supporting a distinction between commercial contracts and those with the consuming public. Consult, for some recent examples, Philippine Air Lines, Inc. v. Texas Engineering \& Manufacturing Co., 181 F. 2d 923 (C.A. 5th, 1950); Charles Lachman Co. v. Hercules Powder Co., 79 F.Supp. 206 (E.D. Pa., 1948); Griffiths v. Henry Broderick, Inc., 27 Wash. 2d 901, 182 P. 2d 18 (1947).

158 For some recent examples, consult Atkins v. Racquet Garage Corp., 177 Pa. Super. 94, 110 A. 2 d 767 (1955) (parking lot, bailees generally); Air Transport Associates, Inc. v. United States, 221 F. 2d 467 (C.A. 9th, 1955) (government operated airport, public service corporations); Oklahoma Natural Gas Co. v. Appel, 226 P. 2d 442 (Okla., 1953) (gas for domestic use, public service corporation); Parkrite Auto Park, Inc. v. Badgett, $316 \mathrm{Ky}$. 630, 242 S.W. 2d 630 (1951) (parking lot, public service corporations); Malone v. Santora, 135 Conn. 286, 64 A. 2d 51 (1949) (parking lot, bailees who serve the public). Earlier examples are collected in Validity of Contractual Provision . . . for Exemption from . . . Consequences of own Negligence, 175 A.L.R. 8 (1948).

MFany of the cases use language of this nature: "[T] he difference is the difference between ordinary bailees on the one hand, and what may be called professional bailees, on the other. They hold themselves out to the public as being possessed of convenient means and special facilities to furnish the service offered for a price. They deal with the public on a uniform 
should be void dates back at least to 1878 when Judge Cooley stated:

The cases of carriers and telegraph companies have been specifically mentioned because it is chiefly in these cases that such contracts are met with. But although the reasons which forbid such contracts have special force in the business of carrying persons and goods, and of sending messages, they apply universally, and should be held to defeat all contracts by which a party undertakes to put another at the mercy of his own faulty conduct. ${ }^{169}$

Cooley was evidently led to this extreme position by the rationale of the carrier doctrine, that is, that contracting out of negligence liability would tend to induce carelessness. If that is the reason for the carrier rule, Cooley's conclusion that there is no justification for limiting the rule to common carriers seems inescapable. The difficulty with his conclusion is not that it is illogical, but that the premise is utterly inconsistent with insurance. ${ }^{160}$ No distinction can be made in terms of inducing carelessness between an exculpatory clause and a contract of liability insurance. ${ }^{161}$ The addition of inequality of bargaining power will not help because the cost of insurance will ultimately be passed on to the consumer if the exculpatory clause is held void; and if the clause is upheld, the service provided will be that much cheaper.

The stated rationale of the rule that a common carrier cannot contract out of negligence liability should be forgotten. It is hoped that the first section of this comment demonstrated that the doctrine itself was never very good law, nor was its putative parent, the doctrine of insurer liability of common carriers, ever very well explained. The influence of these doctrines has generally been pernicious. The almost pathological compulsion which the courts have shown in avoiding the direct issue of the validity of an exculpatory term can, at least in part, be traced to an understandable inability to cope with the stated rationale of the common-carrier rule. A frank recognition of the fact that the rhetoric of that rule is hopelessly inadequate would free the courts to deal with the exculpatory problems in terms of the factual situation which produced the exculpatory clause.

The most important single fact in the factual context of an exculpatory clause should be insurance. By asking a series questions revolving around insurance, courts would go a long way toward solving the problem of "public policy"

basis and at the same time impose or seek to impose predetermined conditions which rob the customer of any equality of bargaining power." Miller's Mut. Fire Ins. Ass'n v. Parker, 234 N.C. 20, 24, 65 S.E. 2d 341, 344 (1951). This manner of speech is reminiscent of the theory of the "common" employments (e.g., common carriers). Consult note 28 supra, and may be a rhetorical example of the continuing influence of the common carrier cases.

${ }^{159}$ Cooley, Torts *687 (1878).

${ }^{160}$ As some courts have recognized. Consult note 150 supra.

161 Though it be recognized that an exculpatory clause may be of broader scope, and perhaps more economical and convenient than an insurance policy, it is submitted that these differences are not an appreciable factor in inducing greater care. Beside the other motivations they seem relatively insignificant. Consult James, op. cit. supra note 3. 
in the field of exculpation.

The basic question is the nature of the injury: how important is it to society that the loss be compensated? Generally speaking, it is most important where personal injuries are involved. Even though the law does not as a rule compel the owner of an injury-producing instrument to compensate all personal injuries regardless of fault, ${ }^{162}$ public policy can legitimately be exerted (as in fact it has been) to prevent an employer ${ }^{163}$ or carrier of persons ${ }^{164}$ from contracting out of negligence liability to his employees or passengers. The result of the law here is to distribute negligently caused losses throughout society by means of insurance. This analysis would lead to the conclusion that where personal injuries are involved a landlord should not be able to avoid liability for negligence. ${ }^{165}$

Where the injury relates to property an exculpatory clause is often simply a means of allocating the burden of insurance expense ${ }^{166}$ and at least in some situations the policy of the law ought to favor this sort of adjustment. For example, there have been a number of recent cases involving the storage of fur coats. The practice ${ }^{167}$ seems to be for the storage company to inquire of the owner whether or not the coat is insured; if it is, the coat is valued for liability purposes at a nominal sum; ${ }^{168}$ if not, then presumably at the market value, and the storage company insures the coat against losses caused by its negligence. This is a sensible way of doing things; the owner of an insured coat gains nothing by

${ }^{162}$ The principal modern exception is workmen's compensation. It is worth noting that the common-carrier "insurer" doctrine never applied to carriers of passengers. This seeming paradox is, however, entirely understandable in light of the origins of the insurer doctrine. Consult 319 supra.

${ }^{163}$ Consult Significance of Comparative Bargaining Power in the Law of Exculpation, 37 Col. L. Rev. 248, 249 n. 7 (1937).

164 Consult ibid., at 255-58.

${ }^{165}$ The cost of insurance reflects the distinction between injury to person and injury to property because as a general rule liability for property damage is limited by the value of the property involved, whereas damages for personal injuries are at least theoretically unlimited. Furthermore it is impossible for a person to insure against some items which are compensable in a personal injury action, e.g., pain and suffering. This means that where the exculpation seeks to avoid liability for personal injuries it cannot be simply a method of shifting from one party to another the cost of insurance. If such exculpation is upheld it means that the person bearing the loss has been denied something which he could not have purchased by way of insurance.

${ }^{166}$ As the English recognize. Consult Rutter v. Palmer, [1922] 2 K.B. 87, and Deacon v. Borradaile, 69 Li.L. Rep. 69 (K.B., 1941).

${ }^{167}$ Consult Samelson v. Harper's Furs, Inc., 20 Conn.Super. 37, 120 A. 2d 429 (1955); Lumberman's Mutual Ins. Co. v. F. Z. Cikra, Inc., 95 N.E. 2d 230 (Ohio App., 1950), rev'd 155 Ohio St. 421, 99 N.E. 2 d 81 (1951); Schoen v. Wallace, 334 IIl. App. 294, 78 N.E. 2d 801 (1948).

${ }^{168}$ This is, of course, a remnant of Hart v. Pennsylvania R. Co., 112 U.S. 331 (1884), and presents the doctrine in its silliest aspect. At least one court has solemnly declared that total exemption from negligence liability by a fur coat storage company would be invalid and then upheld a valuation for a nominal sum, Samelson v. Harper's Furs, Inc., 20 Conn.Sup. 37, 120 A. $2 \mathrm{~d} 429$ (1955). Statements of this nature justify the apparent reluctance of those companies to attempt complete exculpation, but it is difficult to conceive of a less meaningful practice. 
having the storage company insure the coat again. Some courts have recognized this fact, ${ }^{169}$ but others have gone to ridiculous extremes to make the storage company bear the full loss. ${ }^{170}$

The fur coat cases present a situation where one party is apt to have insurance against any loss or damage. ${ }^{171}$ For parties to agree by contract that the insured person should bear the loss whether or not caused by the negligence of the other is something which the law should favor, not discourage. It avoids litigation between insurance companies over duplicate coverage, which, so far as society is concerned, is nothing but wasteful. Another, even better example of this type of situation is the tug boat cases where the exculpatory clause attempted to throw the expense of negligently caused losses onto a party who had almost invariably insured his interest against any kind of loss. ${ }^{172}$

Another situation where exculpation ought to be upheld is where neither party prior to the contract is likely to have insured against loss, but either would

${ }^{169}$ E.g., Fire Ass'n of Philadelphia v. Saks and Co., 125 F.Supp. 874 (S.D.N.Y., 1954), aff'd, 223 F. 2d 822 (C.A. 2d, 1955); Samelson v. Harper's Fur, Inc., 20 Conn.Sup. 37, 120 A. 2d 429 (1955); Blinder v. United States Fire Ins. Co. of N.Y., 103 F.Supp. 902 (N.D. Ill., 1952); Schoen v. Wallace, 334 Ill.App. 294, 78 N.E. 2d 801 (1948) (perhaps the leading case); Eckel v. Trencher Furs, Inc., 191 Misc. 14, 76 N.Y.S. 2d 829 (Mun. Ct. N.Y., 1947) (Compare New York cases cited note 170 infra.).

${ }_{170}$ The New York courts have been the worst offenders. After an unassuming but reasonable decision in favor of the storage company in Eckel v. Trencher Furs, Inc., 191 Misc. 14, 76 N.Y.S. 2d 829 (Mun. Ct. N.Y., 1947) (compare, Taccetta v. Chauncey Rice \& Rogovin Co., 75 F.Supp. 373 [S.D.N.Y., 1947]), the trouble started in Howard v. Handler Bros. \& Winell, Inc., 200 Misc. 600, 103 N.Y.S. $2 d 786$ (S. Ct., 1951). The trial court held a limitation to $\$ 10.00$ void because (1) the defendant did not read the receipt, (2) there was no general custom of valuation limitation shown, and (3) the valuation was so small as to be virtually the same as total exemption from liability. The appellate court affirmed, but not on the grounds stated by the trial court, rather by a process of construction which verges on the incredible, 279 App.Div. 72, 107 N.Y.S. 2d 749 (1st Dep't, 1951). This decision was affirmed without opinion by the Court of Appeals, 303 N.Y. 990, 106 N.E. 2d 67 (1952). The case was followed in Zayenda v. Spain \& Spain, Ltd., 109 N.Y.S. 2 d 87 (Sup. Ct., 1951), aff'd, 280 App.Div. 752, 113 N.Y.S. 2d 115 (1st Dep't, 1952) (somewhat unusual facts); Rappaport v. Phil Gottlieb-Sattler, Inc., 280 App.Div. 424, 114 N.Y.S. 2d 221 (1st Dep't, 1953); Abend v. Haberman, 281 App. Div. 262, 119 N.Y.S. 2d 488 (1st Dep't, 1952); and Rappaport v. Storfer Bros., Inc., 207 Misc. 391, 138 N.Y.S. 2d 584 (City Ct. N.Y., 1955). Perbaps a more egregious example is Lumberman's Mutual Ins. Co. v. F. Z. Cikra, Inc., 155 Ohio St. 421,99 N.E. 2 d 81 (1951), where the Ohio Supreme Court reversed a very sensible lower court decision, 95 N.E. $2 \mathrm{~d} 230$ (Ohio App., 1950).

${ }_{171}$ Another example is the parking lots who have been almost uniformly unsuccessful in their efforts to avoid liability for loss due to theft. Generally speaking, their exculpatory clauses have either been held void or avoided by use of the token doctrine. Consult Jones, The Parking Lot Cases, 27 Geo. L. J. 162 (1938), and Blashfield, Cyclopedia of Automobile Law and Practice $\$ 5040$ (1950). Both of these doctrines lead parking lot owners away from at least one sensible way of solving their problem: a provision in the contract that the parking lot would not be liable to the car owner for any loss for which the latter carried insurance.

172 One of the presumably unintended consequences of the decision in Bisso v. Inland Waterways Corp., 349 U.S. 85 (1955), has been chaos, at least on the inland waterways. The experience which insurance companies had with tug boats had largely been with tugs for large ocean going vessels where the results of liability were apt to be extremely expensive. When tugs on inland waters sought to insure themselves against liability, the rates offered them were way 
if he knew that the loss would fall on him if it occurred. This is fairly typical of the commercial lease and the risk of fire destroying or damaging the premises. Here nothing would be gained by striking down an exculpatory clause because the negligence of the exculpated party caused the loss, and a good deal would be lost if both parties were obliged to insure because of doubt as to whether or not the law would void the exculpatory term.

The most difficult situation arises where one of the two parties would not as a general rule either have insurance or insure if he knew that he was to bear any resulting losses. This is typical of parcel checkrooms and similar service bailments. Perhaps the mere fact that no one will insure unless the bailee is compelled to is sufficient justification for voiding exculpatory efforts in these situations. Apparently courts think so; at least that is the end result of the "token" doctrine. It would be far better if the policy decision were made explicit.

out of line with the risk of towing barges on relatively calm rivers. Presumably this will in time be adjusted so that the end result will be but little more expensive than the old method. It will be interesting to see whether the cost of insurance to the tow will go down because of the possibility of recovery over against the tug.

This illustrates one important aspect of exculpatory law. The effect of surprise due to a change in the law is often more expensive than leaving things as they were. Courts should, in this area, be very hesitant to reverse an established practice such as existed before the Bisso decision.

\section{USE OF EXTRA-RECORD INFORMATION IN CUSTODY CASES}

Litigation resulting from broken homes continually presents courts with the problem of determining, on the basis of the economic, sociological and psychological factors involved in a family relationship, the custody arrangement which will best promote the child's welfare. ${ }^{1}$ Feeling the need for expert advice and distrusting the evidence usually adduced in such proceedings, ${ }^{2}$ many judges consult undisclosed reports of social workers' investigations ${ }^{3}$ into the family situation, which frequently contain information supplied by others as well as the investigator's personal observations. Furthermore, to ascertain the child's feelings many judges interview him in chambers, without the presence of parties

1 Most custody cases state that the sole issue is the child's welfare. Consult Sayre, Awarding Custody of Children, 9 U. of Chi. L. Rev. 672, 676-85 (1942).

2 Consult Alexander, Let's Get the Embattled Spouses out of the Trenches, 18 Law and Contemp. Prob. 98, 99-100 (1953).

${ }^{3}$ Courts recognize social workers as experts in family relations. See, e.g., Fewel v. Fewel, 23 Cal.2d 431, 435, 144 P.2d 592, 594-95 (1943). Several courts feel their help so valuable that custody awards based on conflicting testimony have been remanded for advice of a social worker. Gluckstern v. Gluckstern, 2 App.Div.2d 744, 153 N.Y.S.2d 184 (1956); Withrow v. Withrow, 212 La. 427, 31 So.2d 849 (1947); Boone v. Boone, 150 F.2d 153 (App. D.C., 1945). In West v. West, 208 S.C. 1, 36 S.E.2d 856 (1946), a social worker's report was obtained by the appellate court and relied on in reversing the trial court. 